\title{
Summarized data of genotoxicity tests for designated food additives in Japan
}

\author{
Masami Yamada ${ }^{1,2^{*}}$ and Masamitsu Honma ${ }^{2}$
}

\begin{abstract}
The Ministry of Health, Labour and Welfare has carried out genotoxicity tests for food additives used in Japan in cooperation with the Japan Food Additives Association since 1979. Hayashi et al. summarized these data and published a list of 337 designated additives (Shitei-tenkabutsu in Japanese) with genotoxicity test data in 2000. Thereafter, 29 items were eliminated, and 146 items were newly added. Currently, 454 designated additives are allowed to be used as food additives in Japan. This report, based on the Hayashi report, covers the addition of newly derived genotoxicity test data. Routinely, the bacterial reverse mutation test (Ames test), mammalian cell chromosomal aberration test, and in vivo rodent bone marrow micronucleus test have been used for the evaluation of genotoxicity of food additives. In addition to the data from these tests being updated in this report, it newly includes results of transgenic rodent somatic and germ cell gene mutation assays (TGR assays), incorporated in the Organisation for Economic Co-operation and Development (OECD) test guidelines after 2000. We re-evaluated the genotoxicity of 13 designated food additives considering their TGR data.
\end{abstract}

Keywords: Food additives, Designated additives, Genotoxicity test, Ames test, Transgenic rodent gene mutation assay

\section{Background}

Since 1979, as part of the safety reassessment of food additives, the Ministry of Health, Labour and Welfare (MHLW; prior to January 2001, the Ministry of Health and Welfare) has carried out mutagenicity tests annually in cooperation with the Japan Food Additives Association. In 2000, Dr. M. Hayashi (former Head of Division of Genetics and Mutagenesis at the National Institute of Health Sciences (NIHS)) and colleagues summarized the mutagenicity data for 337 designated additives, 187 existing additives (natural additives), 49 natural fragrances, and seven general food and drink additives from fiscal year (FY) 1979 to FY1998 [1] (hereafter referred to as the "Hayashi report"). Since then, concerning designated additives, 29 items have been eliminated due to abolition of form classification or for other reasons (Table 1), and 146 items have been newly added (Table 2). In this report, which is based on the Hayashi report, data on newly tested items have been added, and

\footnotetext{
* Correspondence: m-yamada@nda.ac.jp

${ }^{1}$ Department of Applied Chemistry, National Defense Academy, 1-10-20, Hashirimizu, Yokosuka-shi, Kanagawa 239-8686, Japan

${ }^{2}$ Division of Genetics and Mutagenesis, National Institute of Health Sciences, 3-25-26, Tonomachi, Kawasaki-ku, Kawasaki-shi, Kanagawa 210-9501, Japan
}

mutagenicity data for a total of 454 designated food additives is summarized in Table 3.

\section{How the data were summarized}

The following set of three tests has traditionally been used to evaluate mutagenicity of food additives: reverse mutation assay (Ames test) using bacteria; chromosomal aberration test using cell culture (CA); and micronucleus test using mice $(\mathrm{MN})$. The Hayashi report summarized the data from the results of these three tests. Two new tests suitable for the evaluation of food additives were subsequently added in the OECD Genotoxicity Test Guidelines. The two adopted test guidelines are: "Genetic mutation test using transgenic rodent somatic and germ cells (TG 488)" (the TGR test); and "In vivo mammalian alkaline comet assay (TG 489)" (the comet test). Results using these assays are included in this paper (Table 3). While both tests have advantages for the evaluation of genotoxicity in specific tissues, the TGR test is intended as a mutagenicity test (similar to the Ames test) therefore the weighting of TGR results is generally higher due to its high correlation with carcinogenicity. 
Table 1 List of designated food additives eliminated after 2000 (As of October 6, 2016)

\begin{tabular}{|c|c|c|}
\hline Name & Date & Reason \\
\hline Aluminum Potassium Sulfate (dried) (syn: Burnt Alum) & June 30, 2000 & Integrated into "Aluminum Potassium Sulfate" \\
\hline Ferrous Pyrophosphate & June 30, 2000 & Distribution and usage records have not been confirmed \\
\hline Sodium Sulfite (anhydrous) & June 30, 2000 & Integrated into "Sodium Sulfite" \\
\hline Tetrasodium Pyrophosphate (anhydrous) & June 30, 2000 & Integrated into "Tetrasodium Pyrophosphate" \\
\hline $\begin{array}{l}\text { Aluminum Ammonium Sulfate (dried) (syn: Burnt } \\
\text { Ammonium Alum) }\end{array}$ & June 30, 2000 & Integrated into "Aluminum Ammonium Sulfate" \\
\hline $\begin{array}{l}\text { Disodium Hydrogen Phosphate (anhydrous) (Disodium } \\
\text { Phosphate (anhydrous)) }\end{array}$ & June 30,2000 & Integrated into "Disodium Hydrogen Phosphate" \\
\hline $\begin{array}{l}\text { Sodium Dihydrogen Phosphate (anhydrous) (Monosodium } \\
\text { Phosphate (anhydrous)) }\end{array}$ & June 30, 2000 & Integrated into "Sodium Dihydrogen Phosphate" \\
\hline Tertiary Sodium Phosphate (anhydrous) & June 30, 2000 & Integrated into "Tertiary Sodium Phosphate" \\
\hline Choline phosphate & June 30, 2000 & Distribution and usage records have not been confirmed \\
\hline Methyl O-Acetylricinoleate & June 30,2000 & Distribution and usage records have not been confirmed \\
\hline Citric Acid (anhydrous) & June 30, 2000 & Integrated into "Citric Acid" \\
\hline Ferrous Sulfate (dried) & June 30, 2000 & Integrated into "Ferrous Sulfate" \\
\hline Sodium Acetate (anhydrous) & June 30, 2000 & Integrated into "Sodium Acetate" \\
\hline Sodium Hydroxide (crystal) & June 30, 2000 & Integrated into "Sodium Hydroxide" \\
\hline Sodium Carbonate (crystal) & June 30, 2000 & Integrated into "Sodium Carbonate" \\
\hline Sodium Starch Phosphate & June 4, 2009 & Production and usage have not been confirmed \\
\hline
\end{tabular}

The date and the reasons for disappearance are indicated

When searching for items that had not been subjected to mutagenicity testing, it was felt desirable that all test outcomes were discovered without exception. Thus, in Table 3, data from journals other than Hayashi report are included; for example, data published in the Annual Report of the Tokyo Metropolitan Research Laboratory of Public Health (originally published in Japanese). Reports that were surveyed, including journals other than Hayashi report, are listed at the end of this paper. Results of the three tests used initially are mainly copied from the Hayashi report (also published in Japanese). Data reevaluated or added after the Hayashi report include results from outsourced testing laboratories accredited by the MHLW as part of the "Projects for safety of food additives."

In the main Table, the superscript symbols "H22" and "H23" indicate results commissioned in tests conducted in Fiscal Year 2010 (FY2010) and FY2011, respectively. Test results from the Risk Assessment Reports prepared by the Food Safety Commission (FSC) are also included; these are indicated by superscript "FSC", and the URL for the Risk Assessment Reports of the item is given in the reference list. Note that reference numbers in the text are not given in numeric order but in the order of appearance in Table 3. The eliminated and newly added substances are listed in Tables 1 and 2, respectively. In Table 3, the item numbers from Table 2 are shown underlined.

\section{Commentary for 13 items newly subjected to the TGR test}

1) Five items positive for Ames and chromosome aberration tests while negative for in vivo micronucleus test Sodium nitrite (No. 6 in Table 3)

Ames testing was performed at the highest dose of 10 mg/plate using TA1535, TA98, TA1537, TA94, TA92 in FY1979, and positive results were obtained with TA100 and TA1535 regardless of S9mix [2]. Subsequently, using TA97 and TA102, a statistically significant increase in the number of revertants (maximum dose $10 \mathrm{mg} /$ plate) was reported in both strains regardless of S9mix [3]. However, the result is given as negative in Table 3 since the number of reverted colonies did not reach twice of the number for the negative control. Many positive results of Ames tests were reported in this item, thus, mutagenicity was suspected for this substance [4].

For chromosomal abnormalities, the chromosome aberration test using Chinese Hamster lung (CHL) was performed at a maximum dose of $1.0 \mathrm{mg} / \mathrm{mL}$ without $\mathrm{S} 9 \mathrm{mix}$, and strong induction of structural abnormalities was reported [2]. Subsequently, in vivo bone marrow micronucleus tests using ddY mice were carried out under three conditions: a single intraperitoneal (i.p.) dose of $200 \mathrm{mg} /$ $\mathrm{kg}$ body weight; four i.p. doses at $50 \mathrm{mg} / \mathrm{kg}$ body weight at 24-h intervals; and a single oral dose of $400 \mathrm{mg} / \mathrm{kg}$ body weight [5], all results being reported as negative. 
Table 2 List of items that have been added to the designated food additives (As of October 6, 2016)

\begin{tabular}{ll}
\hline No. ${ }^{\text {a }}$ & Name \\
\hline 2 & chlorous acid water \\
4 & nitrous oxide \\
9 & calcium L-ascorbate \\
13 & L-ascorbic acid 2-glucoside \\
16 & asparaginase \\
17 & acesulfame potassium \\
18 & acetylated distarch adipate \\
19 & acetylated oxidized starch \\
20 & acetylated distarch phosphate \\
24 & acetaldehyde \\
25 & sodium selenite pentahydrate \\
26 & azoxystrobin \\
28 & advantame \\
29 & B-apo-8'-carotenal \\
30 & (3-amino-3-carboxypropyl) dimethylsulfonium chloride \\
35 & amylalcohol \\
36 & ammonium alginate \\
37 & potassium alginate \\
44 & calcium alginate \\
46 & ammonium isovalerate \\
47 & isoamylalcohol \\
51 & isogunalin \\
\hline 3 &
\end{tabular}

isoquinoline

isovaleraldehyde

isobutanol

isobutyraldehyde (isobutanal)

isopropanol

isopentylamine

mixture of 2-ethyl-3,5-dimethylpyrazine and 2-ethyl-3, 6-dimethylpyrazine

2-ethylpyrazine

3-ethylpyridine

2-ethyl-3-methylpyrazine

2-ethyl-5-methylpyrazine

2-ethyl-6-methylpyrazine

5-ethyl-2-methylpyridine

ethers

octanoic acid

starch sodium octenyl succinate

peracetic acid

canthaxanthin

xylitol (alias xylit)

triethyl citrate

sodium ferrous citrate (sodium iron citrate)

Table 2 List of items that have been added to the designated food additives (As of October 6, 2016) (Continued)

\begin{tabular}{ll}
\hline No. $^{{ }^{2}}$ & Name \\
\hline 127 & sodium gluconate \\
128 & glutamyl-valyl-glycine \\
130 & monoammonium L-glutamate \\
132 & monocalcium $d$ - $L$-glutamate \\
134 & monomagnesium dl-L-glutamate \\
135 & calcium silicate \\
136 & magnesium silicate \\
140 & ketones \\
150 & calcium acetate \\
156 & starch acetate \\
165 & calcium saccharin \\
168 & calcium oxide \\
169 & oxidized starch \\
172 & hypochlorous acid water \\
174 & hypobromous acid water \\
176 & 2,3-diethylpyrazine \\
177 & 2,3-diethyl-5-methylpyrazine \\
189 & fatty acids \\
191 & aliphatic higher aldehydes (except those generally \\
192 & recognized as highly toxic) \\
& aliphatic higher hydrocarbons (except those generally
\end{tabular}
recognized as highly toxic)

2,3-dimethylpyrazine

2,5-dimethylpyrazine

2,6-dimethylpyrazine

2,6-dimethylpyridine

potassium dl-bitartrate (potassium hydrogen dl-tartrate or potassium hydrogen $d$-tartrate)

disodium $\mathrm{dl}$-tartrate (disodium $\mathrm{dl}$-tartrate)

magnesium hydroxide

sucralose (trichlorogalactosucrose)

calcium stearate

magnesium stearate

sodium stearoyl lactylate

calcium sorbate

thiamine thiocyanate (vitamin B1 thiocyanate)

thioethers (except those generally recognized as highly toxic)

thiols (thioalcohols) (except those generally recognized as highly toxic)

5,6,7,8-tetrahydroquinoxaline

2,3,5,6-tetramethylpyrazine

terpene hydrocarbons

all-racemic -a-tocopheryl acetate

$\mathrm{R}, \mathrm{R}, \mathrm{R}$-a-tocopheryl acetate 
Table 2 List of items that have been added to the designated food additives (As of October 6, 2016) (Continued)

\begin{tabular}{|c|c|}
\hline No. $^{a}$ & Name \\
\hline 272 & trimethylamine \\
\hline 273 & 2,3,5-trimethylpyrazine \\
\hline 276 & nisin \\
\hline 277 & natamycin \\
\hline 284 & carbon dioxide (carbonic acid, gas) \\
\hline 287 & potassium lactate \\
\hline 291 & neotame \\
\hline 303 & valeraldehyde \\
\hline 306 & biotin \\
\hline 308 & bisbentiamine (benzoylthiamine disulfide) \\
\hline 311 & 1-hydroxyethylidene-1, 1-diphosphonic acid \\
\hline 313 & hydroxycitronellal dimethylacetal \\
\hline 314 & hydroxypropyl distarch phosphate \\
\hline 315 & hydroxypropyl cellulose \\
\hline 316 & hydroxypropyl starch \\
\hline 317 & hydroxypropyl methylcellulose \\
\hline 318 & piperidine \\
\hline 321 & sunflower lecithin \\
\hline 323 & pyrazine \\
\hline 325 & pyrimethanil \\
\hline 328 & pyrrolidine \\
\hline 334 & pyrrole \\
\hline 339 & 2-(3-phenylpropyl) pyridine \\
\hline 340 & phenethylamine \\
\hline 341 & $\begin{array}{l}\text { phenol ethers (except those generally recognized as } \\
\text { highly toxic) }\end{array}$ \\
\hline 342 & $\begin{array}{l}\text { phenols (except those generally recognized as } \\
\text { highly toxic) }\end{array}$ \\
\hline 343 & $\begin{array}{l}\text { ferrocyanides (potassium ferrocyanide (potassium } \\
\text { hexacyanoferrate (ii)), calcium ferrocyanide (calcium } \\
\text { hexacyanoferrate (ii)), sodium ferrocyanide (sodium } \\
\text { hexacyanoferrate (ii)) }\end{array}$ \\
\hline 344 & butanol \\
\hline 345 & butylamine \\
\hline 346 & butyraldehyde \\
\hline 350 & fludioxonil \\
\hline 352 & propanol \\
\hline 353 & propionaldehyde \\
\hline 369 & 2-pentanol (syn: sec-amylalcohol) \\
\hline 370 & trans-2-pentenal \\
\hline 371 & 1-penten-3-ol \\
\hline 372 & aromatic alcohols \\
\hline 373 & $\begin{array}{l}\text { aromatic aldehydes (except those generally recognized } \\
\text { as highly toxic) }\end{array}$ \\
\hline 377 & polysorbate 20 \\
\hline
\end{tabular}

Table 2 List of items that have been added to the designated food additives (As of October 6, 2016) (Continued)

\begin{tabular}{ll}
\hline No. $^{{ }^{2}}$ & Name \\
\hline 378 & polysorbate 60 \\
379 & polysorbate 65 \\
380 & polysorbate 80 \\
381 & polyvinylpyrroridone \\
382 & polyvinylpolypyrrolidone \\
394 & 5-methylquinoxaline \\
395 & 6-methylquinoline \\
396 & 6,7-dihydro-5-methyl-5 h-cyclopentapyrazine \\
398 & 1-methylnaphthalene \\
400 & 2-methypyrazine \\
401 & 2-methylbutanol \\
402 & 3-methyl-2-butanol \\
403 & 2-methylbutyraldehyde \\
404 & trans-2-methyl-2-butenal, (e)-2-methyl-2-butenal \\
405 & 3-methyl-2-butenal \\
406 & 3-methyl-2-butenol \\
417 & Lactones (except those generally recognized as \\
422 & highly toxic) \\
431 & calcium 5'-ribonucleotide \\
439 & potassium sulfate \\
440 & distarch phosphate \\
443 & monostarch phosphate \\
452 & trimagnesium phosphate (syn: Magnesium phosphate, \\
\hline & magnesium monohydrogen phosphate \\
& phosphated distarch phosphate \\
\hline $4 n$ & consistent with those underined in Table 3
\end{tabular}

${ }^{a}$ numbers are consistent with those underlined in Table 3

In FY2009, TGR testing using gpt delta mice was performed in the liver and glandular stomach for confirmation of in vivo mutagenicity. These organs were selected because the liver metabolizes many substances and is highly sensitive in this assay, and the glandular stomach is the organ first exposed to the substance under test with oral administration. The mutagenicity that was previously observed in the Ames test did not occur in vivo, since the TGR results were negative in both organs after 28 days of administration via drinking water at a maximum dose of $5000 \mathrm{mg} / \mathrm{kg}$ body weight [H21(FY2009)].

L-Cysteine monohydrochloride (No. 179 in Table 3)

Ames testing was carried out using TA100, TA98, TA2637, TA94, at a maximum dose of $10 \mathrm{mg} /$ plate with or without S9mix in FY1982. Positive results were reported for TA100 with S9mix, and for TA2637 with and without S9mix [6]. Chromosomal aberration tests were 


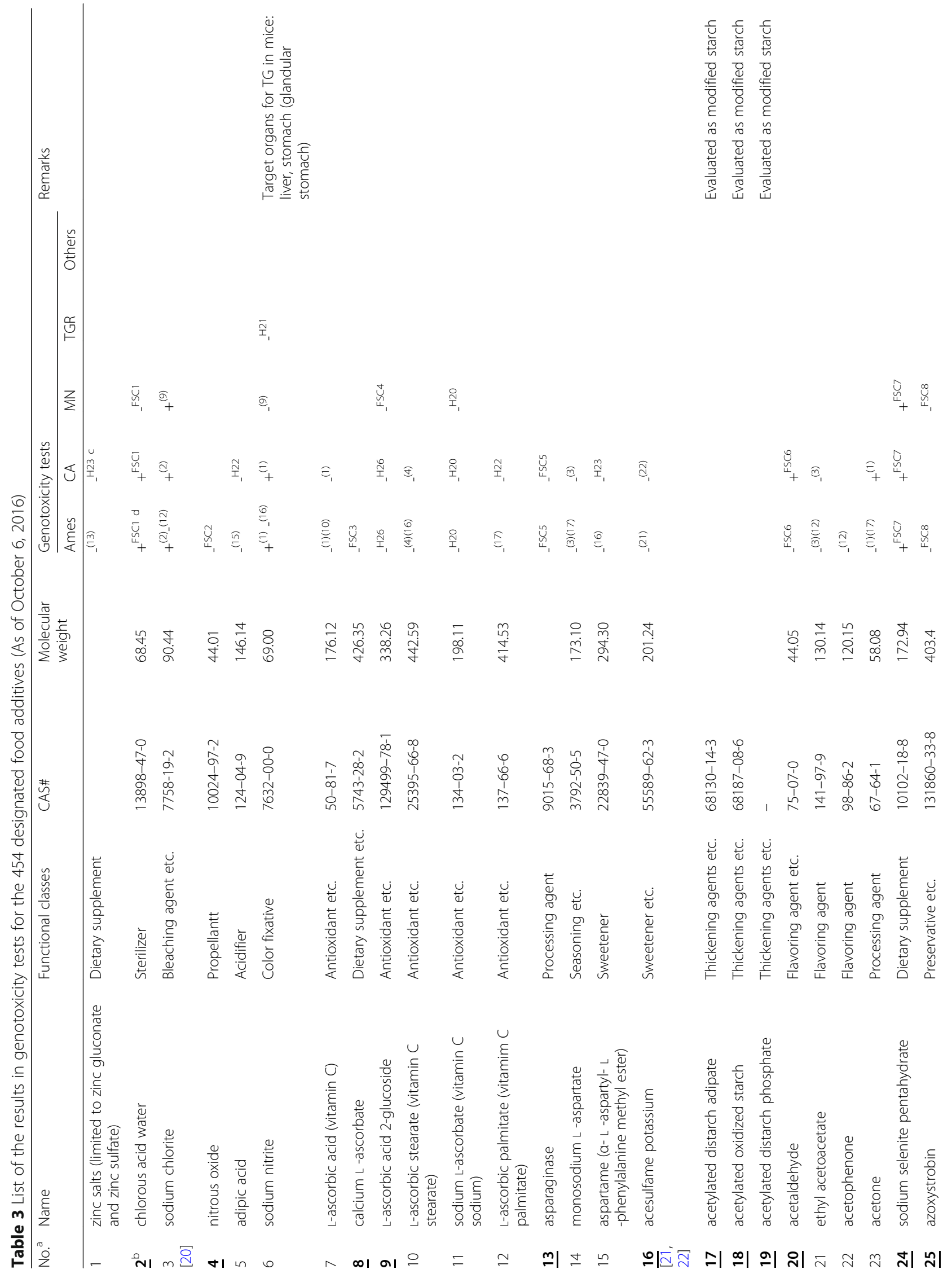




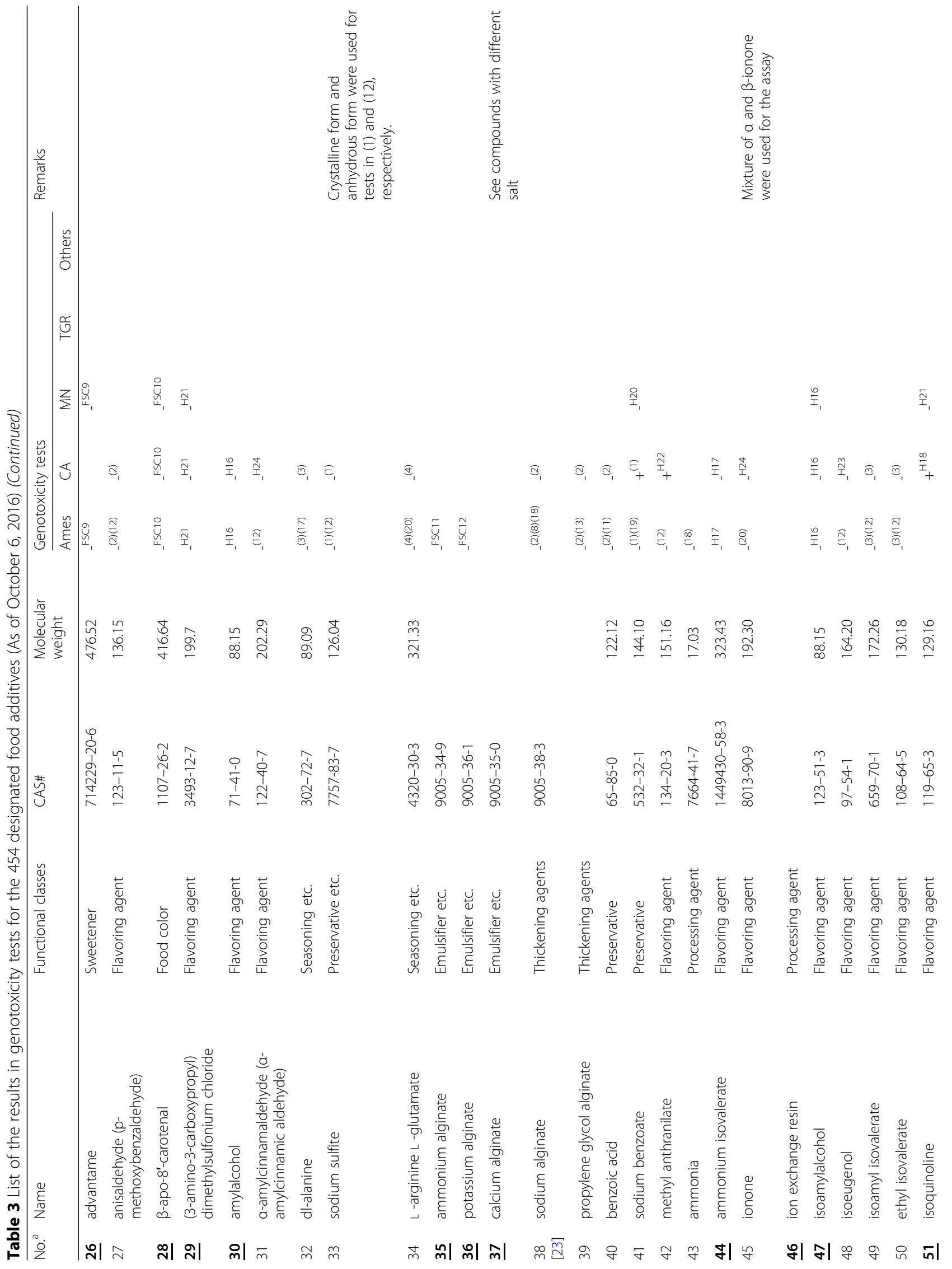


Yamada and Houma Genes and Environment

(2018) 40:27

Page 7 of 28

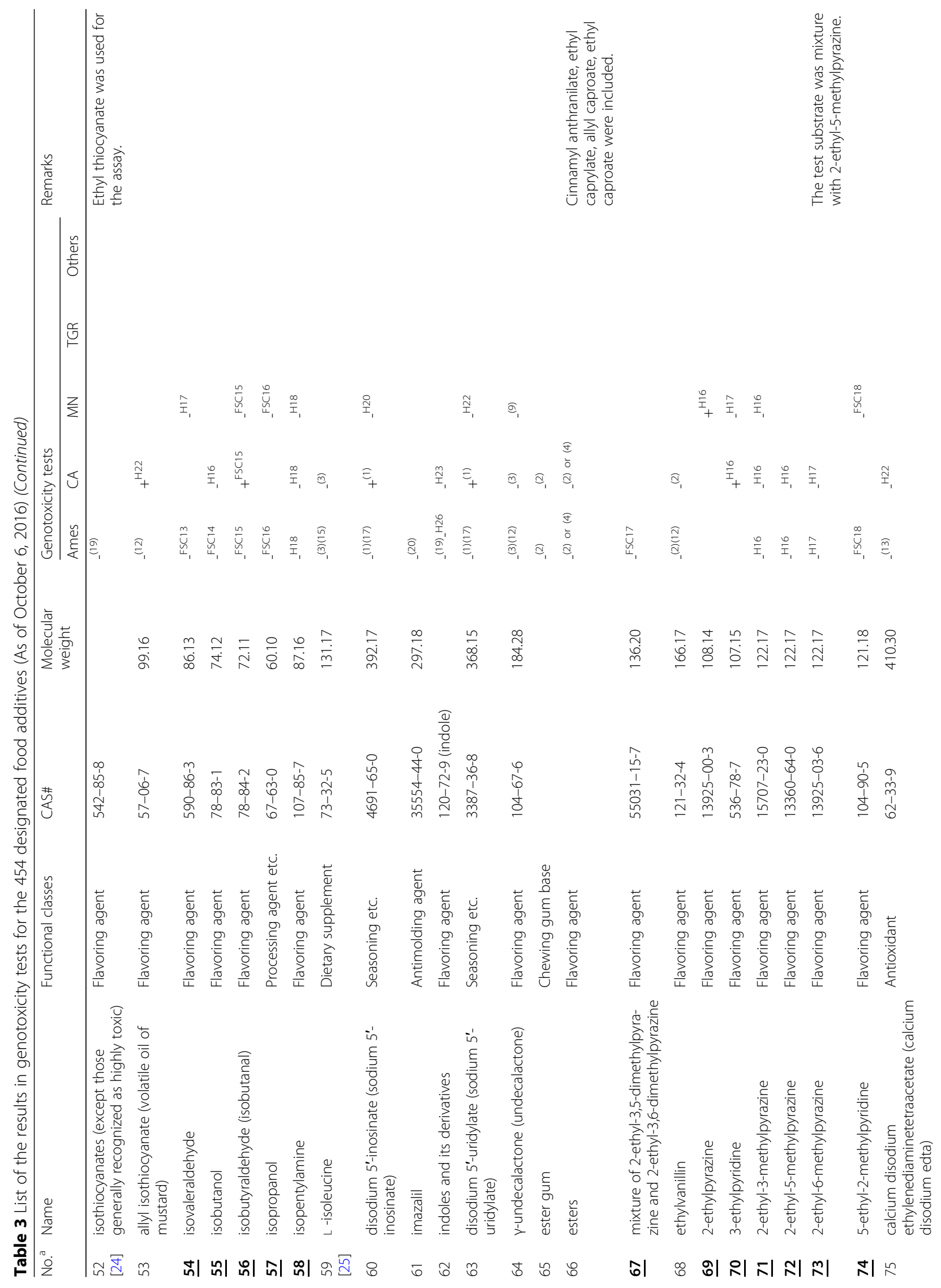




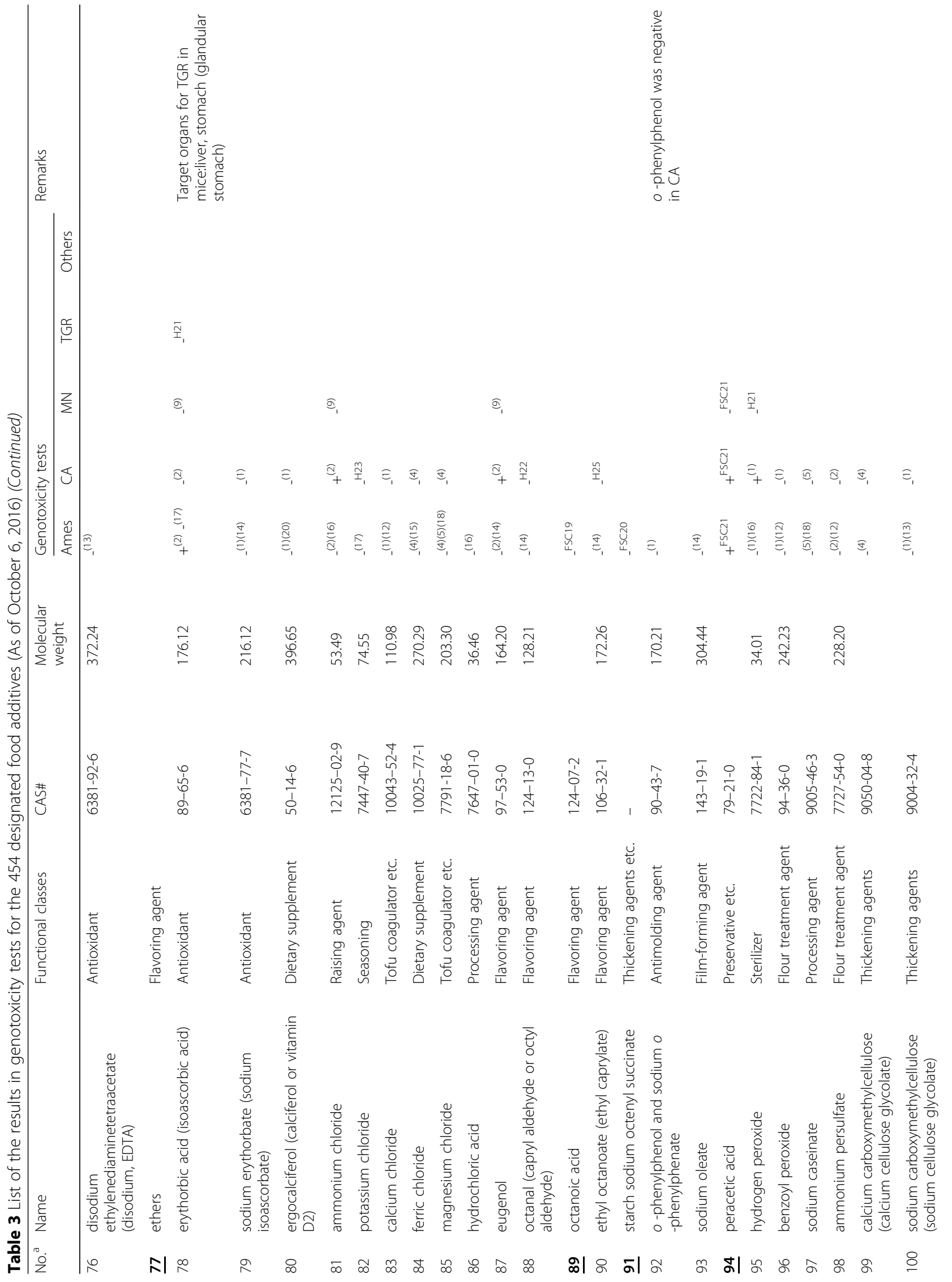




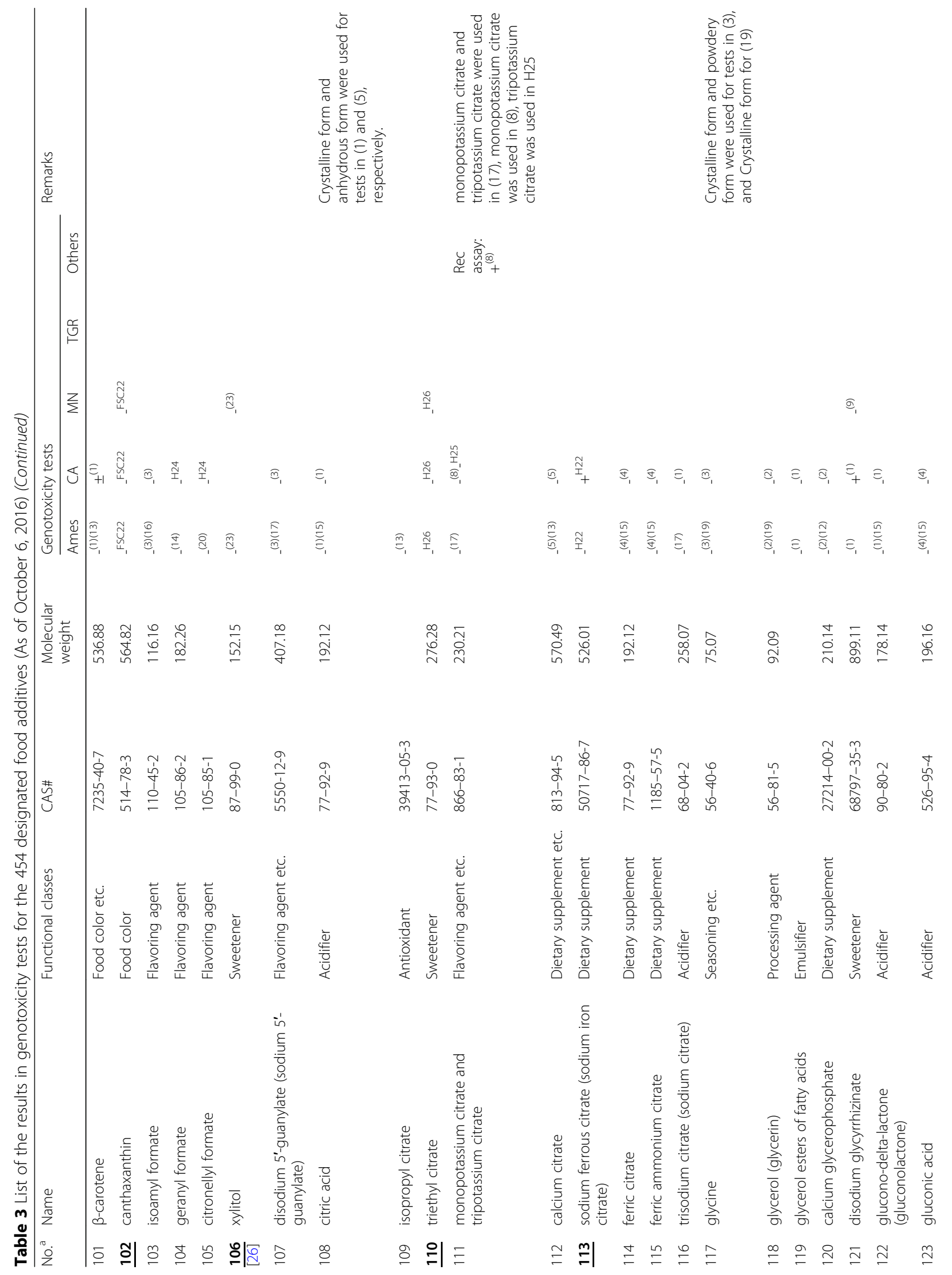




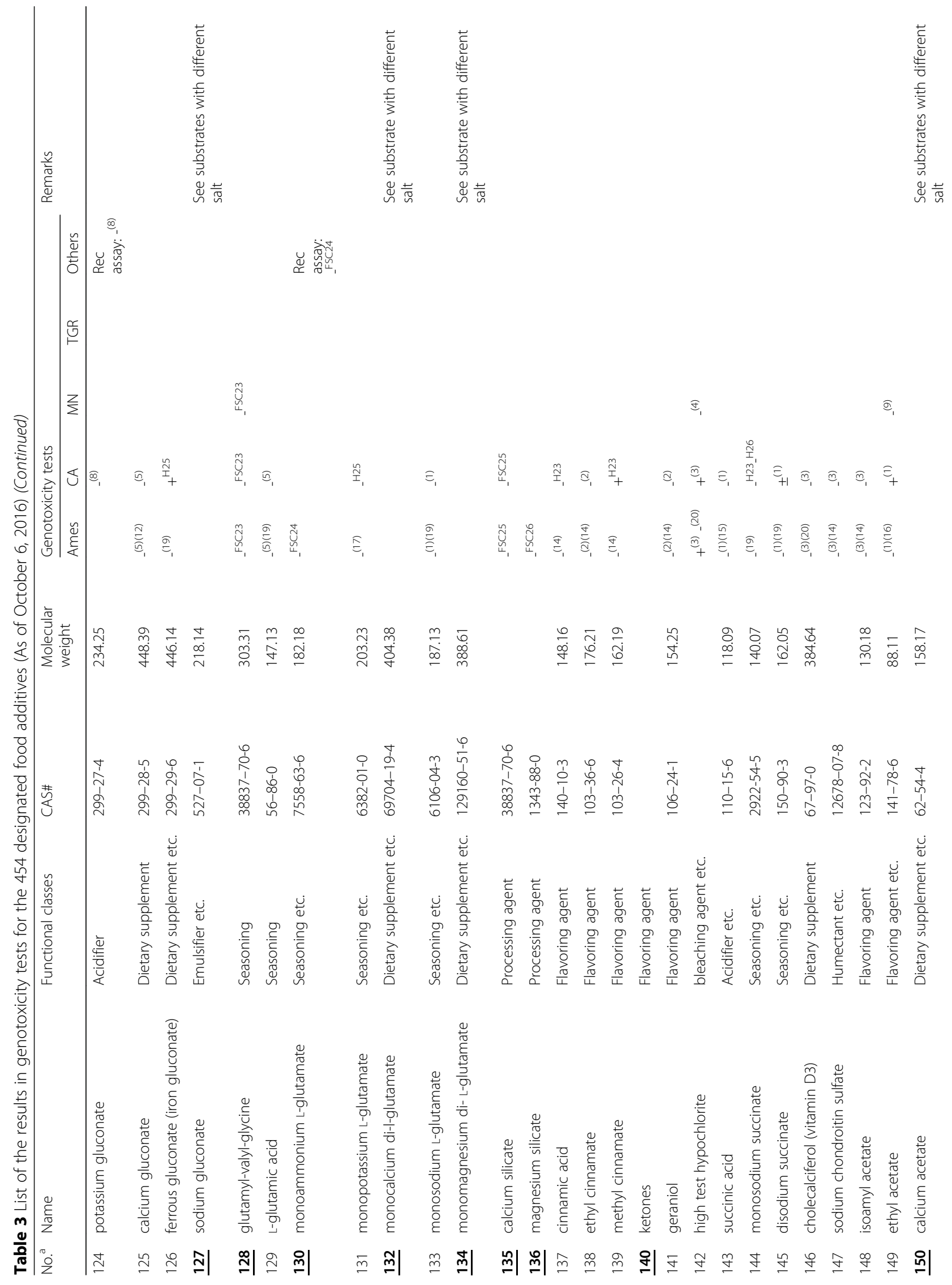




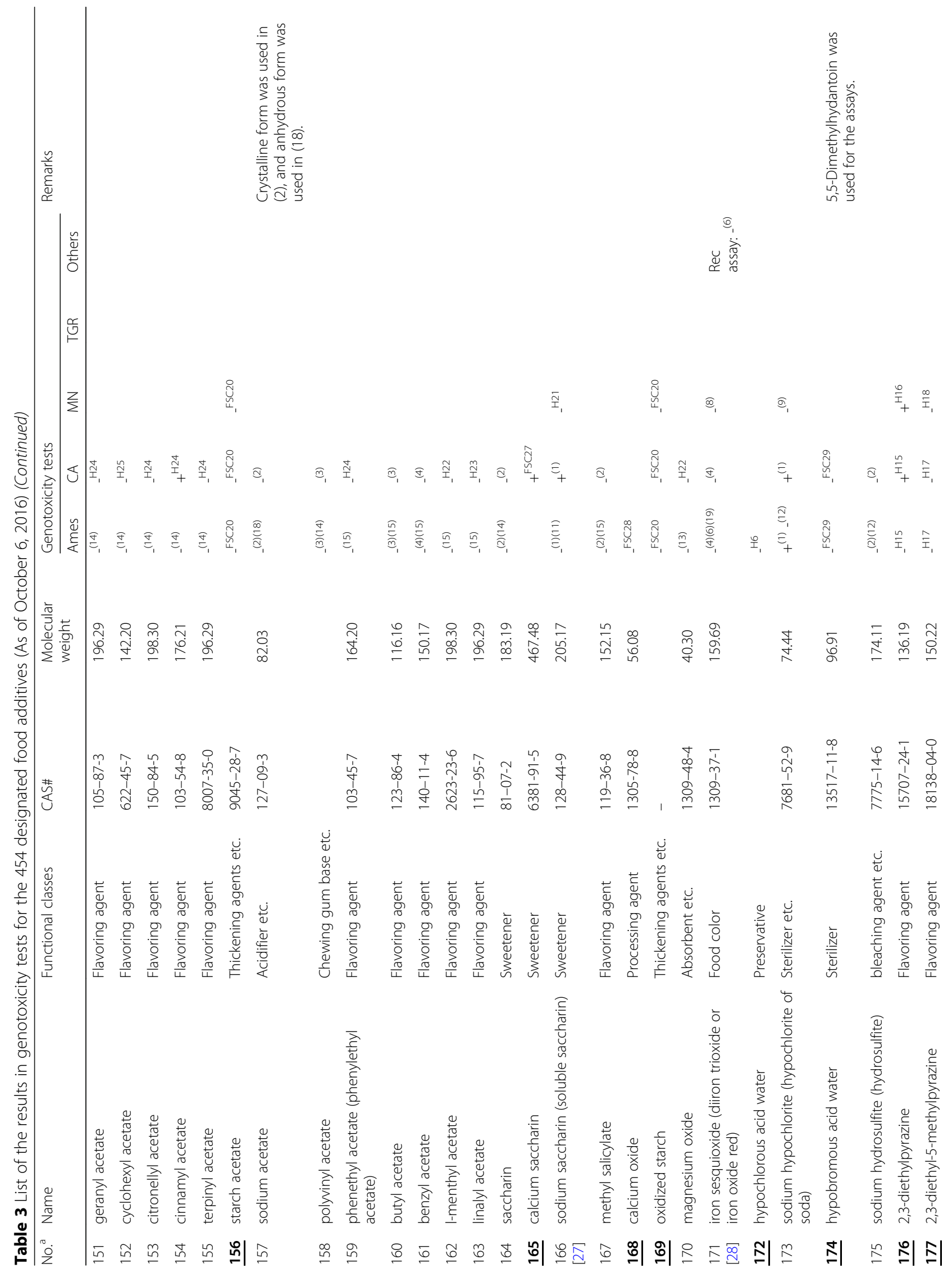




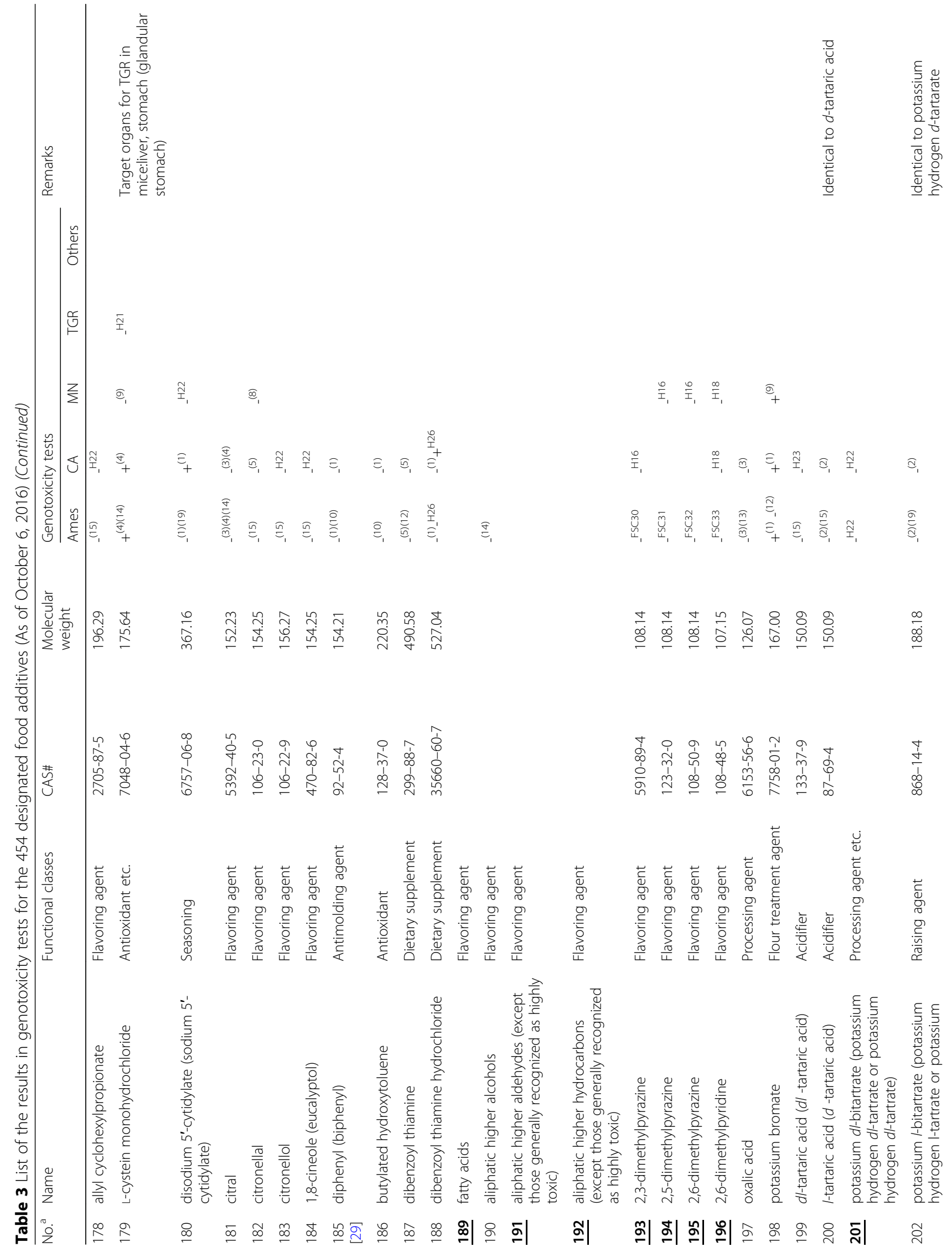




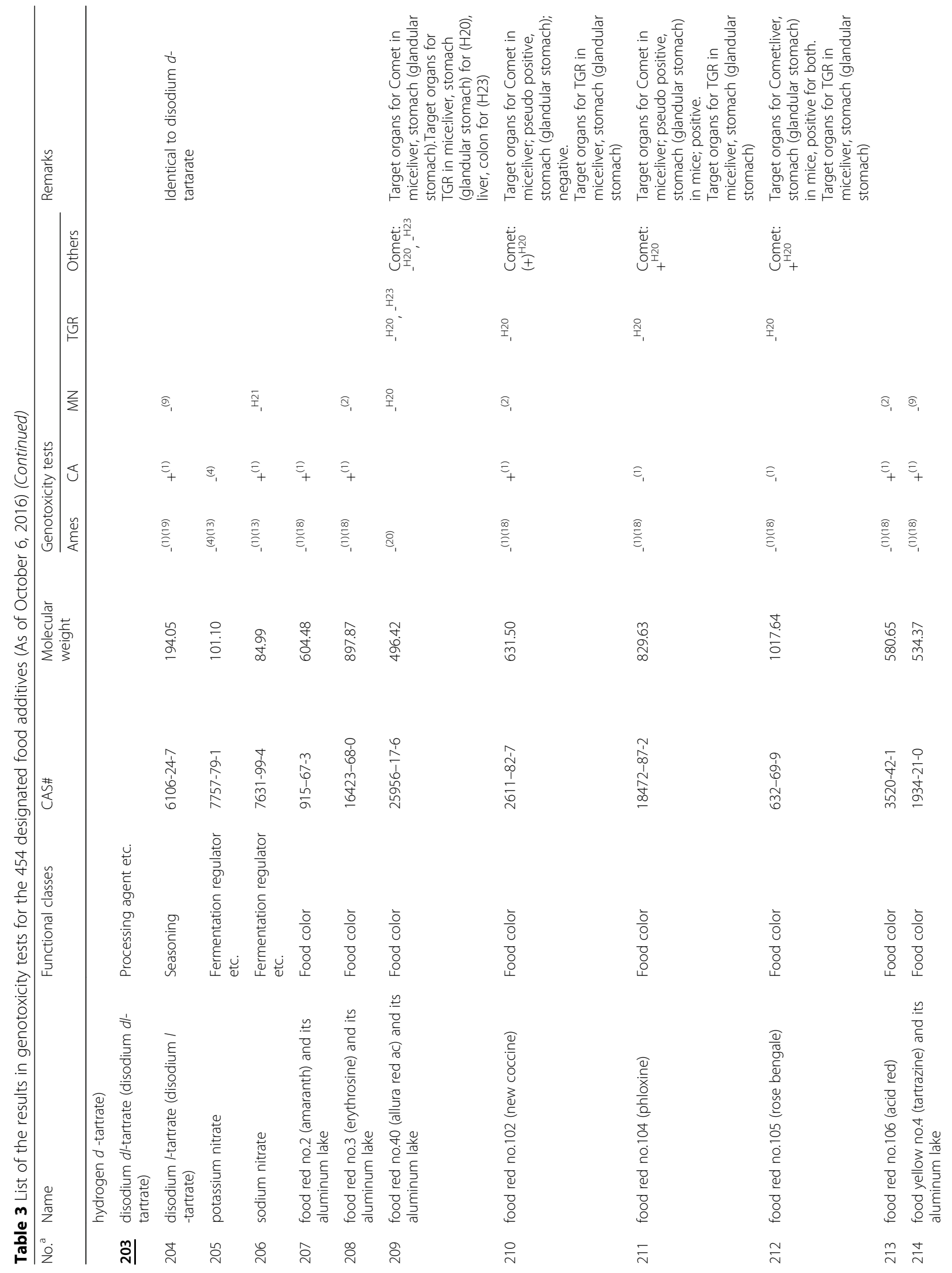




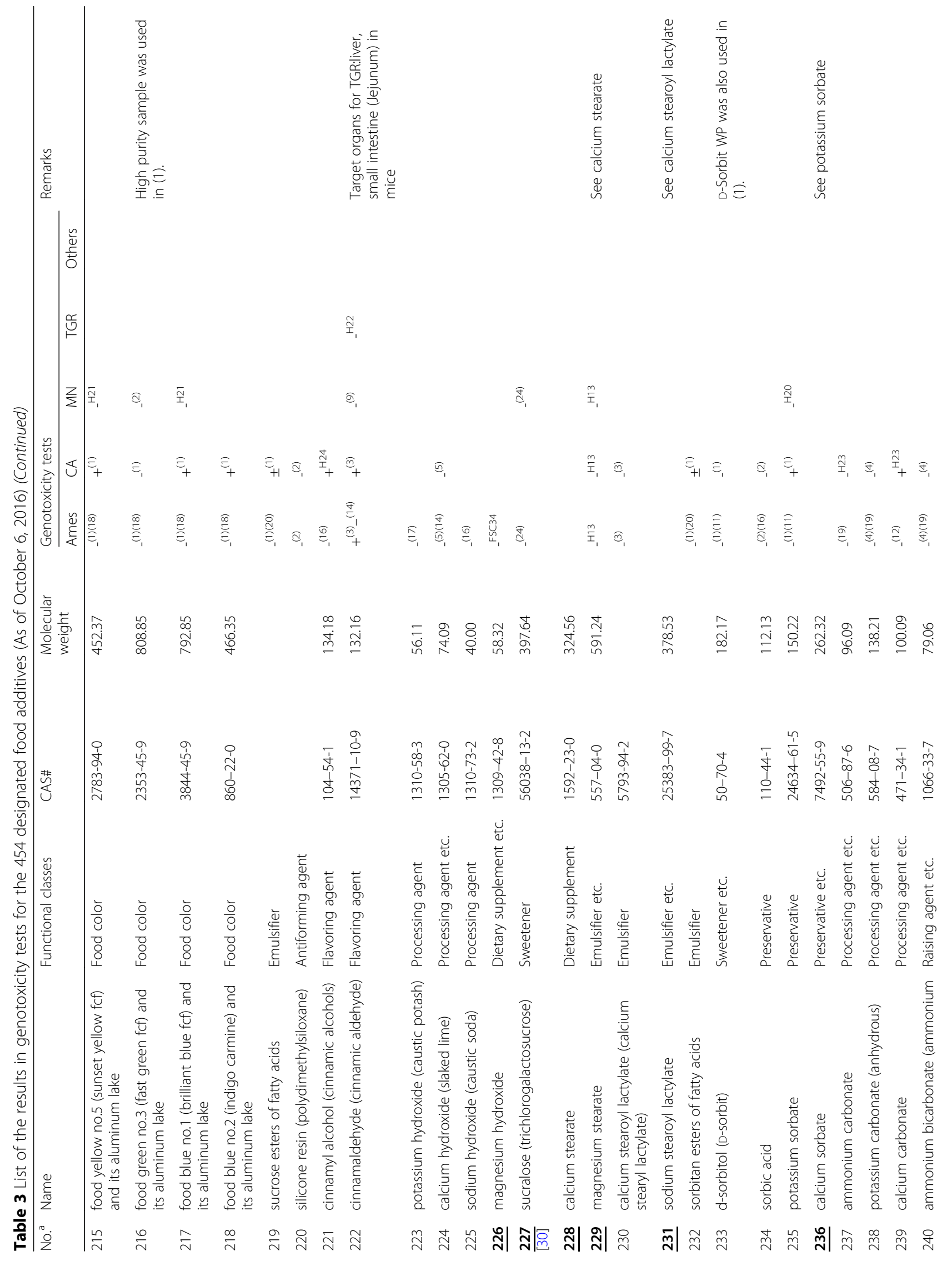




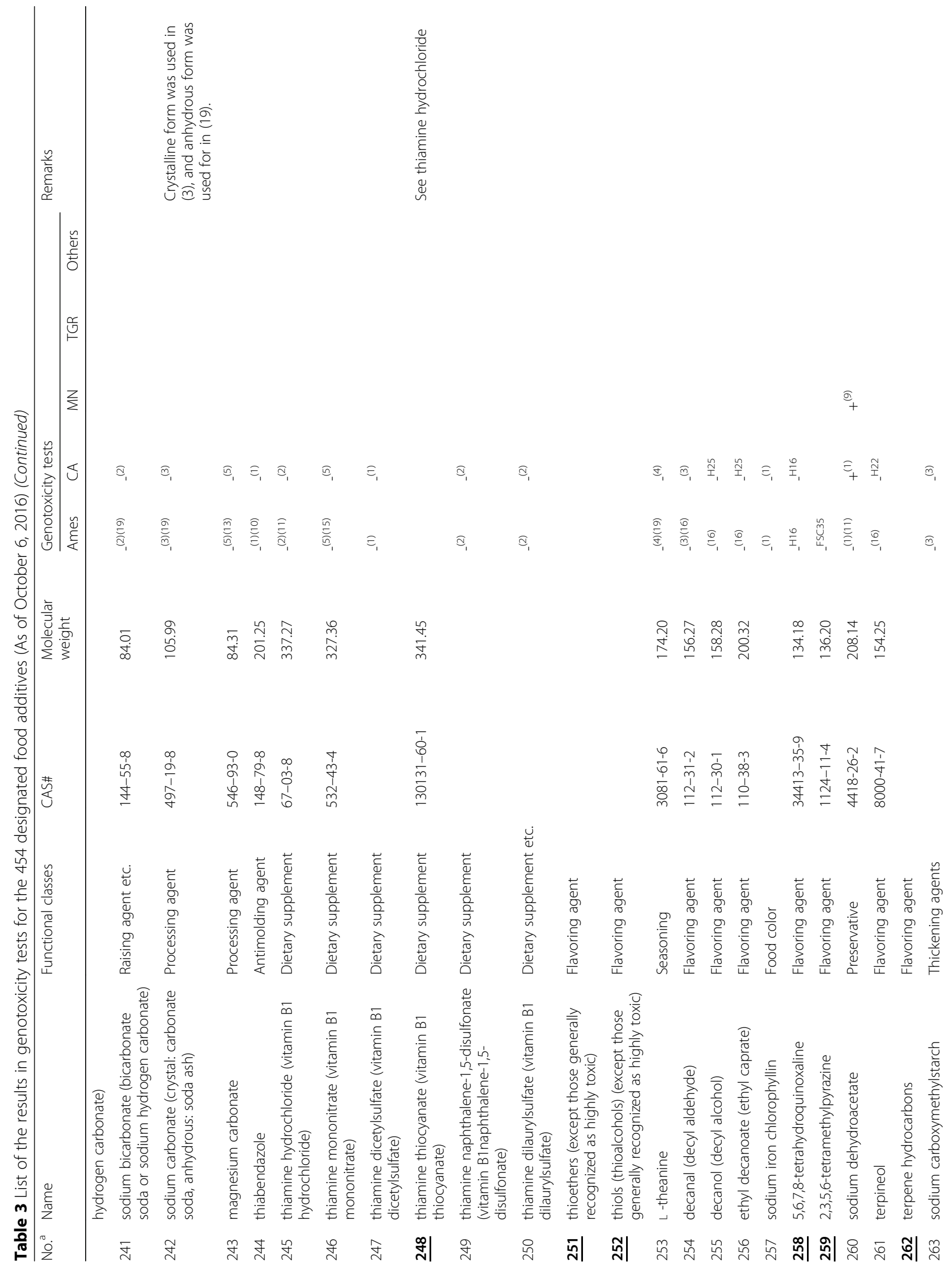




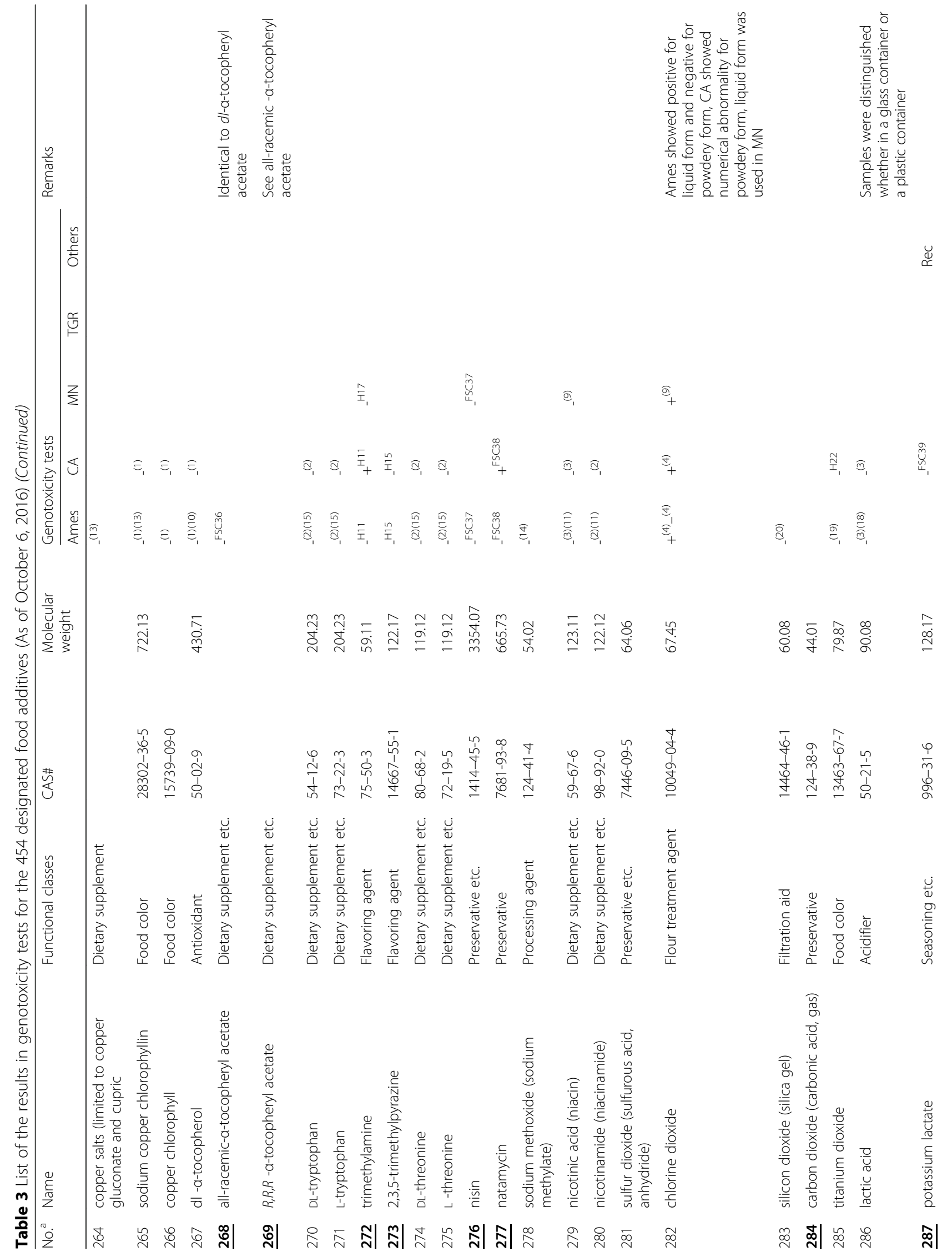




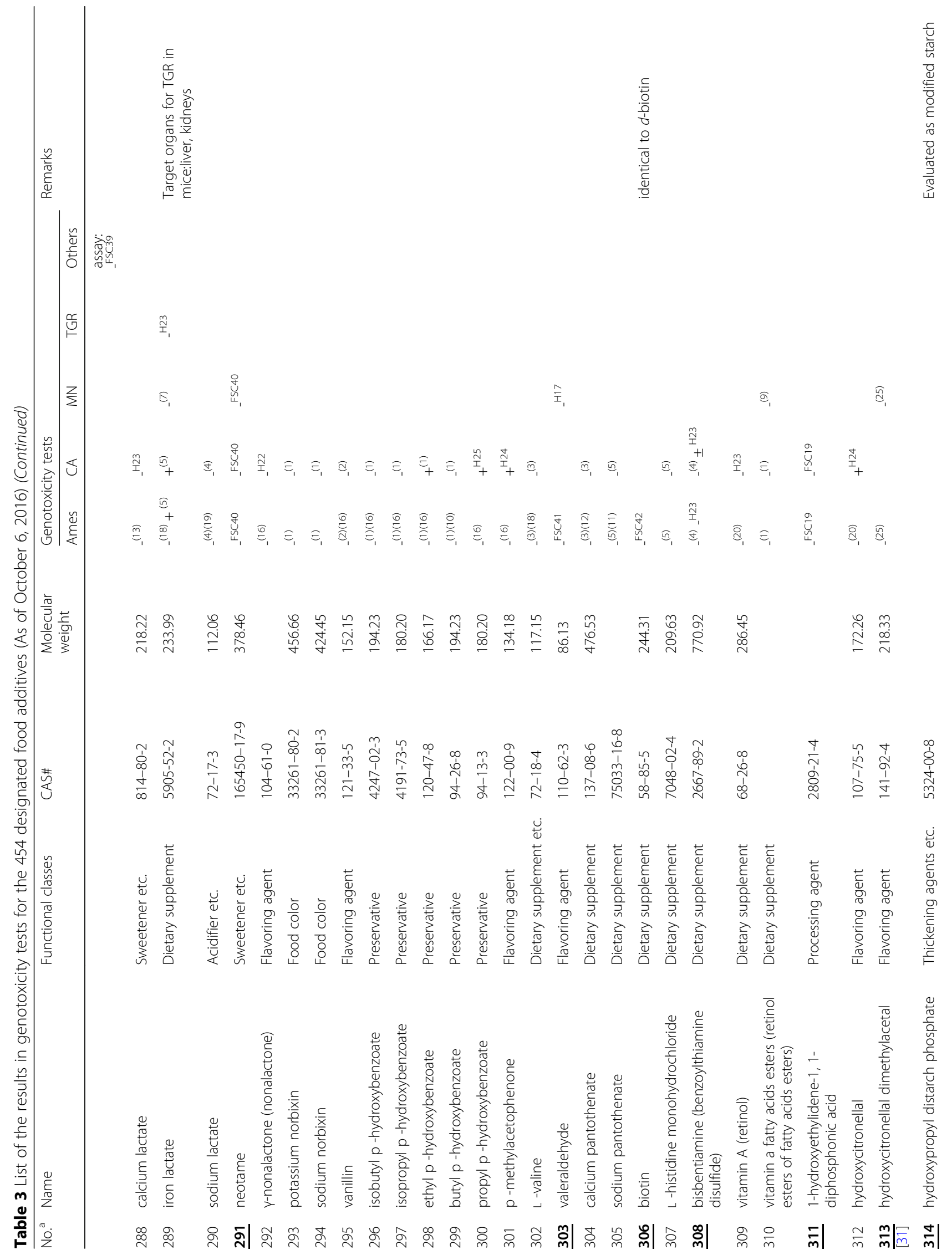




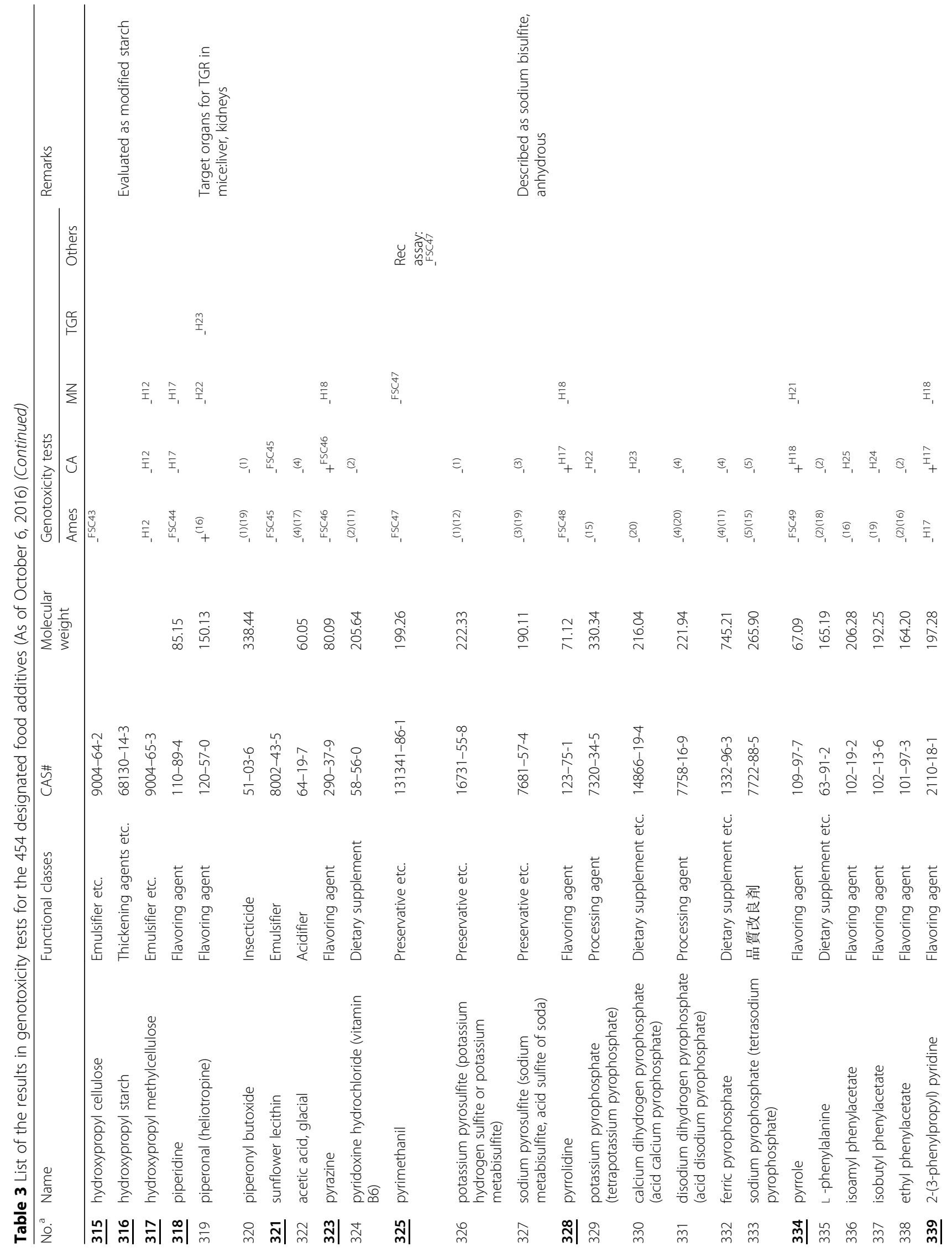




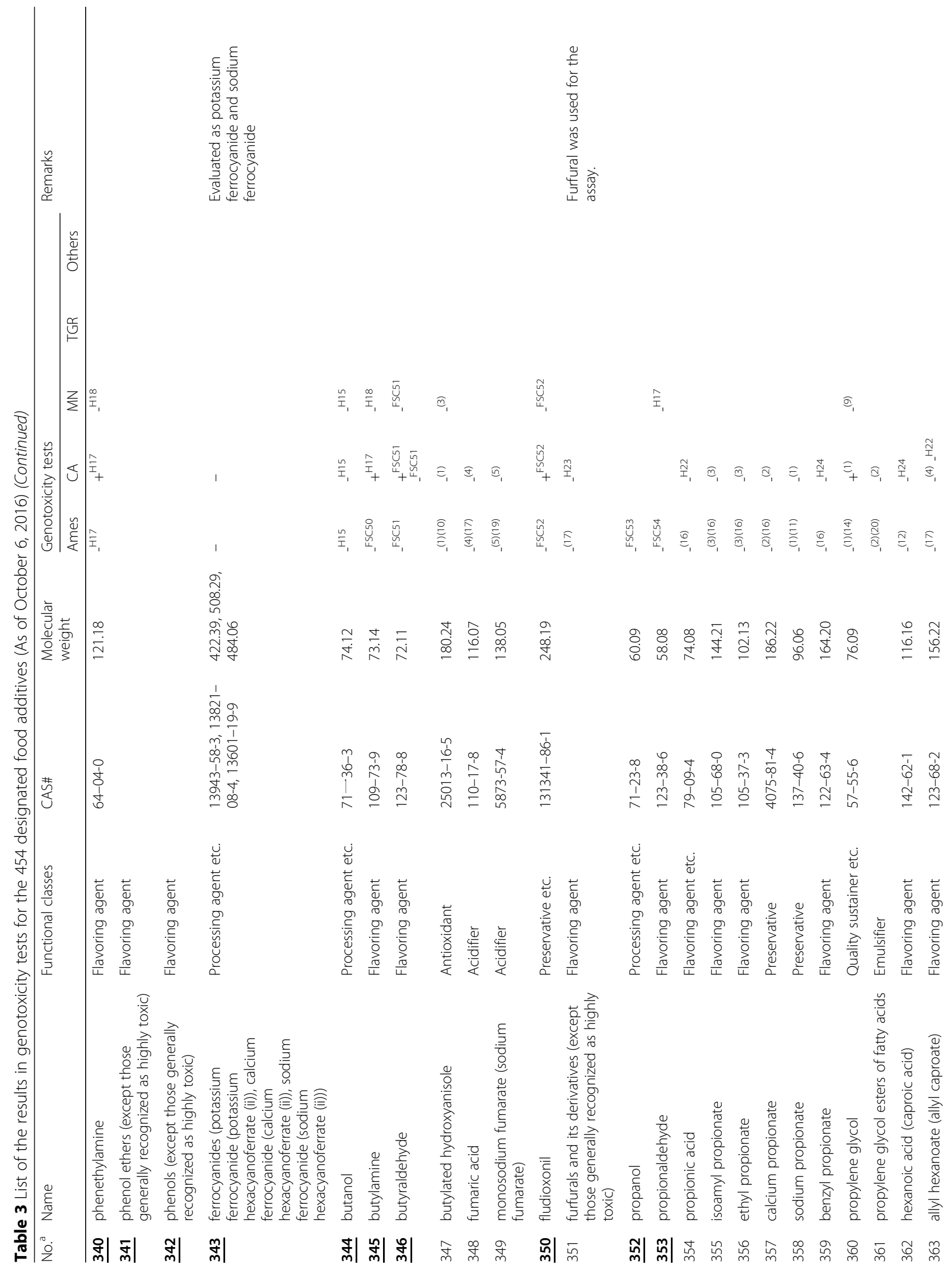




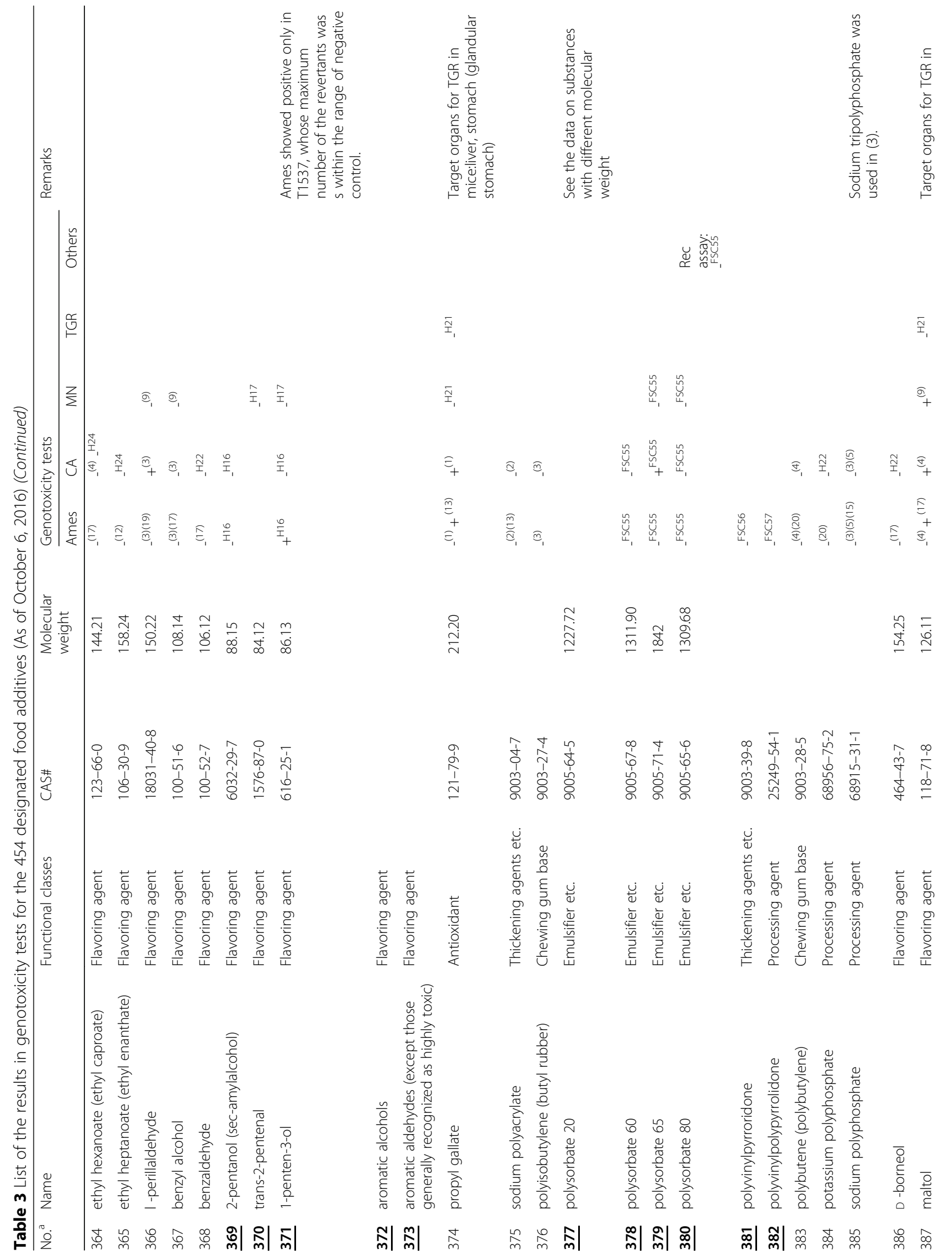




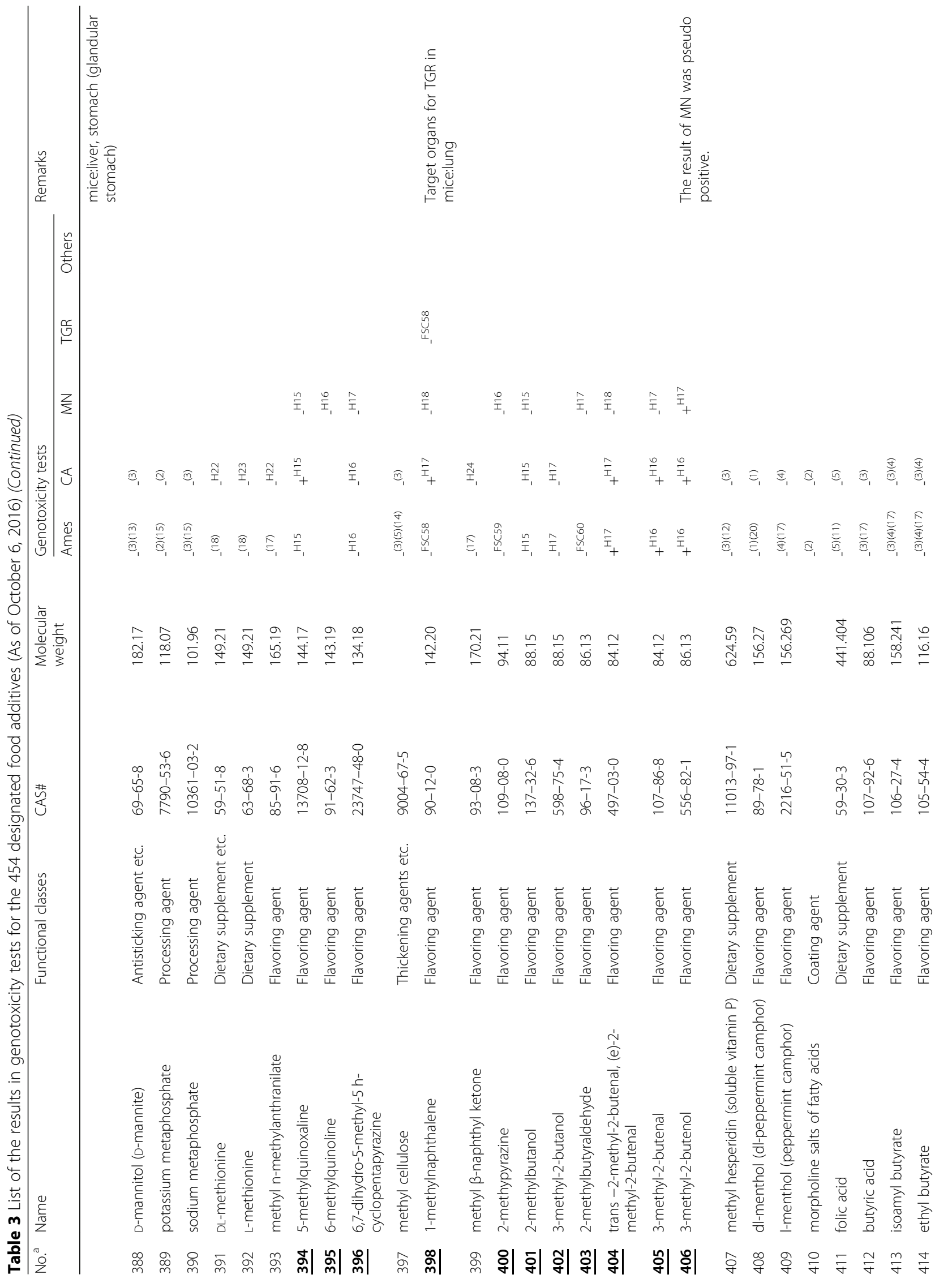


Yamada and Houma Genes and Environment $\quad$ (2018) 40:27

Page 22 of 28

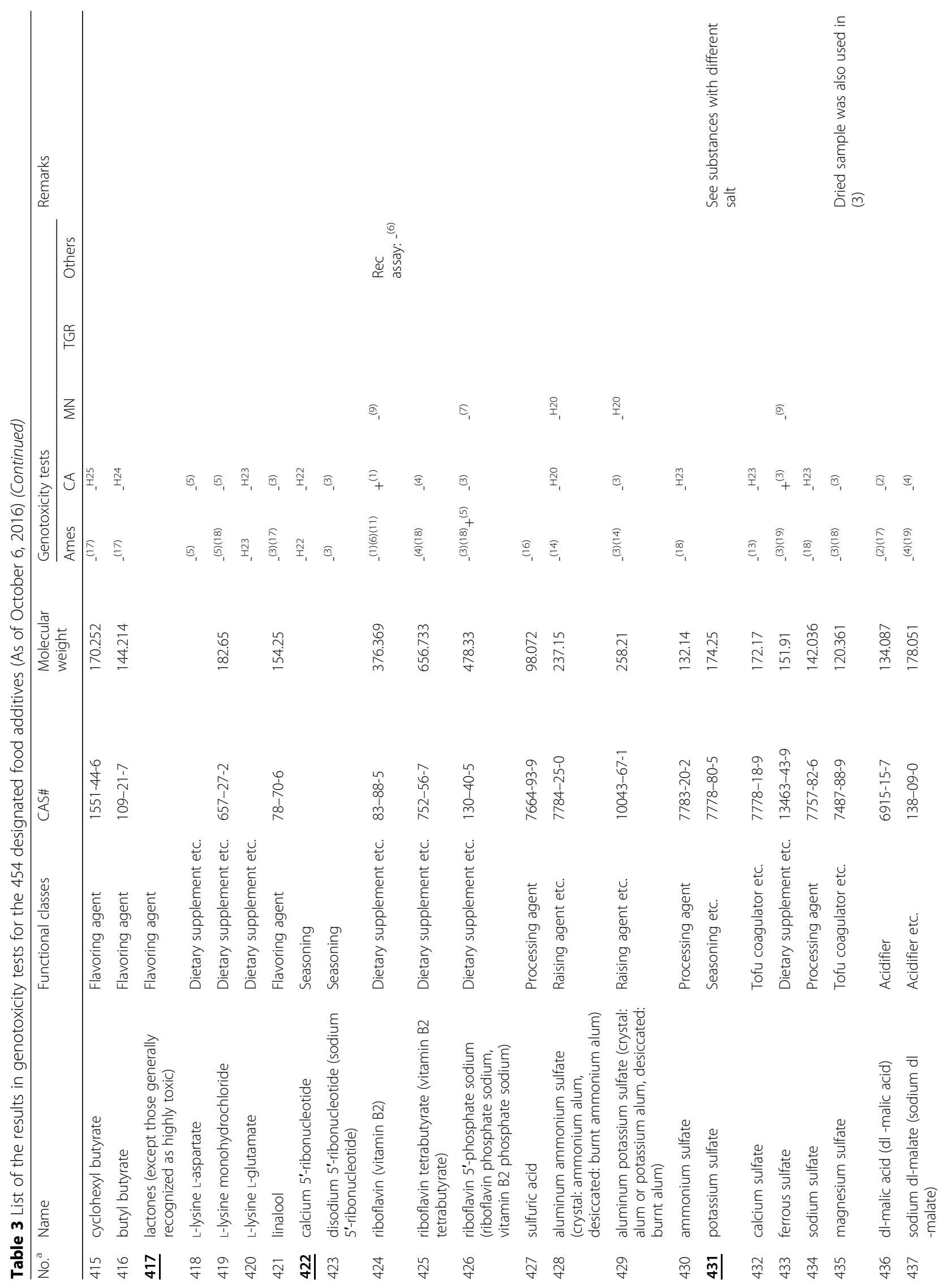


Yamada and Houma Genes and Environment

(2018) 40:27

Page 23 of 28

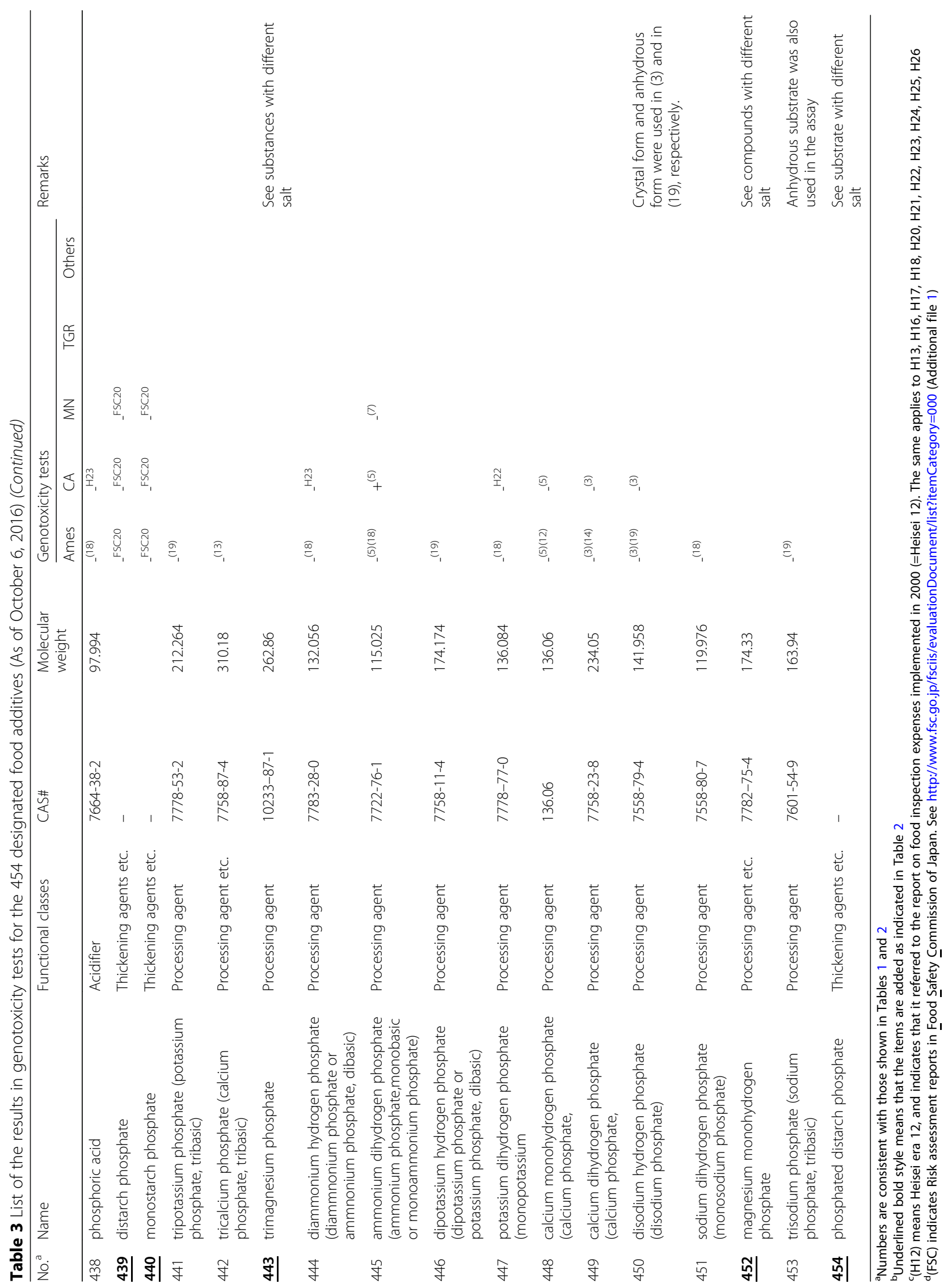


performed using CHL cells without S9mix and structural abnormalities were induced (maximum dose was $2 \mathrm{mg} /$ $\mathrm{mL}$ ) [6]. Subsequently, the Ames test was conducted at Tokyo Metropolitan Research Laboratories of Public Health (TMRL) using TA97 and TA102 with and without S9mix at a maximum dose of $10 \mathrm{mg} /$ plate, and positive results were reported under all conditions [7]. Since genotoxicity was detected in vitro, bone marrow micronucleus test using ddY mice was conducted in 1986. The test results were negative for single i.p. doses of 125, 250 and $500 \mathrm{mg} / \mathrm{kg}$ body weight [5].

In FY2009, TGR testing using gpt delta mice was performed in the liver and glandular stomach for confirmation of in vivo mutagenicity; the results were negative in both organs following oral gavage for 28 days at a maximum dose of $1000 \mathrm{mg} / \mathrm{kg}$ body weight [H22(FY2010)].

Despite positive in vitro results, it was concluded that L-cysteine hydrochloride is not genotoxic in living organisms because results were negative in in vivo $\mathrm{MN}$ and TGR tests.

\section{Cinnamaldehyde (No. 222 in Table 3)}

Ames tests were performed at a maximum dose of $0.5 \mathrm{mg} /$ plate with and without S9mix using TA100, TA1535, TA98, TA1537, TA92, TA97 in FY1981. Only TA100 showed positive results regardless of the metabolic activation in this report [8]. In the chromosome aberration test simultaneously carried out using CHL cells, structural abnormalities were induced without S9mix (maximum dose $0.015 \mathrm{mg} / \mathrm{mL}$ ) [8]. Subsequently, Ames tests were carried out at TMRL using TA97 and TA102 at a maximum dose of $0.1 \mathrm{mg} /$ plate; results were negative regardless of metabolic activation [7]. Since genotoxicity was detected in vitro, in vivo bone marrow MN testing was conducted in FY1986. Mice (ddY) were given a single i.p. injection at 125, 250 and $500 \mathrm{mg} / \mathrm{kg}$ body weight and the results were negative [5].

We conducted TGR tests in the liver and small intestine (jejunum) using gpt delta mice to confirm in vivo mutagenicity in FY2010 and FY2011. The reason for choosing the small intestine as the target organ is that it is the first in the gastrointestinal tract to be exposed to substances administered orally. Mice were dosed by oral gavage at 125 , 250,500 and $1000 \mathrm{mg} / \mathrm{kg}$ body weight for 28 days, and mutagenicity was investigated for the animals dosed at 500 and $1000 \mathrm{mg} / \mathrm{kg}$ body weight. Negative results were obtained in both organs [H22(FY2010)].

Despite showing genotoxicity in vitro, it was concluded that cinnamaldehyde does not show genotoxicity in living organisms because results were negative in in vivo $M N$ and TGR tests.

\section{Iron lactate (No. 289 in Table 3)}

Ames testing was carried out in FY1983 and the results were positive without S9mix in TA97, TA102 and
TA2637 at the highest dose of $5.0 \mathrm{mg} /$ plate, and negative in TA100 and TA98 with and without S9mix [9]. Chromosomal aberration testing using CHL cells conducted in the same year induced structural abnormalities without S9mix (maximum dose $2.5 \mathrm{mg} / \mathrm{mL}$ ) [9]. Subsequently, Ames tests were conducted at TMRL using TA97 and TA102, yielding negative results with and without S9mix [10]. The maximum dose in this study, $1.0 \mathrm{mg} /$ plate, is considered to be insufficient. In vivo $\mathrm{MN}$ testing using ddY mice was conducted in FY1986 (single i.p. administration of $30 \mathrm{mg} / \mathrm{kg}$ body weight, and four separate i.p. doses of $7.5 \mathrm{mg} / \mathrm{kg}$ body weight/day), with negative results [11].

In FY2011, TGR tests in the liver and kidney were carried out using gpt delta mice to confirm in vivo mutagenicity. The reason for using the kidney as the target organ is that nephrotoxicity was observed in macroscopic examinations. After doses of 250, 500 and 1000 $\mathrm{mg} / \mathrm{kg}$ body weight for 28 days by oral gavage, mutation was investigated at doses of 500 and $1000 \mathrm{mg} / \mathrm{kg}$ body weight. Since the results were negative in both organs [H23(FY2011)], it was concluded that iron lactate does not induce mutation in vivo.

\section{Propyl gallate (No. 374 in Table 3)}

Ames testing was carried out in TA100, TA98, TA1537 at $500 \mu \mathrm{g} /$ plate in FY1979, and negative results were obtained regardless of metabolic activation [2]. Subsequently, Ames tests were carried out at TMRL using TA97 and TA102, and at the maximum dose of $0.1 \mathrm{mg} /$ plate it was found that TA102 showed a statistically significant increase in the number of revertants regardless of metabolic activation [12]. TA100 and TA1535 mainly detect base substitution occurring in GC base pairs, while TA102 mainly reveals substitution in AT base pairs. Thus, these results (negative in TA100 and TA1535, positive in TA102) suggest that propyl gallate is reactive with AT base pairs. The negative results for TA98, TA1537 and TA97 indicate that the probability of inducing a frameshift mutation is low. Five out of six tests showed positive results at doses higher than $50 \mu \mathrm{g} /$ $\mathrm{mL}$, but an unusual pattern was shown regarding dose correlation for which the mechanism is unknown.

Since the above results suggested that propyl gallate induces base substitution with AT base pairs in vitro, TGR testing was performed in liver and glandular stomach using gpt delta mice in FY2009 [H21(FY2009)]. Repeated administration over 28 days produced negative results for both organs at the highest dose of $1000 \mathrm{mg} /$ $\mathrm{kg}$ body weight. Thus, the mutagenicity of propyl gallate was detected in vitro, but not considered to be detected in vivo.

After chromosomal aberration testing in FY1979 it was reported that structural abnormalities were induced 
in CHL after $24 \mathrm{~h}$ treatment at a dose of $0.04 \mathrm{mg} / \mathrm{mL}$ without S9mix [2]. To investigate the risk of chromosomal aberration, in vivo bone marrow $\mathrm{MN}$ testing was conducted in FY2009, with negative results at the maximum dose of $1000 \mathrm{mg} / \mathrm{kg}$ body weight (administered twice) [H21(FY2009)]. Therefore, although chromosomal abnormalities were detected in vitro, they were not in vivo.

From the results detailed above, propyl gallate was considered to be non-genotoxic to living bodies.

2) Two items negative for chromosome aberration and in vivo micronucleus tests while positive for Ames test Erythorbic acid (isoascorbic acid)(No. 78 in Table 3)

This substance was positive only in TA100 regardless of S9mix (highest dose $50 \mathrm{mg} /$ plate) in the Ames test using the strains TA100, TA98, TA1535, TA98, TA1537, TA92 and TA94 in FY1980 [13]. In chromosomal aberration tests using CHL cells, a negative result was reported at the highest dose of $0.25 \mathrm{mg} / \mathrm{mL}$ without S9mix [13]. In the Ames test conducted at TMRL using TA97 and TA102, a statistically significant increase in the number of revertants was reported in both strains regardless of S9mix (maximum dose $10 \mathrm{mg} /$ plate) [14]. However, the result is given as negative in Table 3 since the number of revertants did not reached twice of the number of the negative control. Subsequently, an in vivo bone marrow MN test using ddY mice was performed, and this substance showed negative when administered in a single dose of $1500 \mathrm{mg} / \mathrm{kg}$ body weight (at the maximum) or as four treatments (at 24-h intervals) at $750 \mathrm{mg} / \mathrm{kg}$ body weight (at the maximum).

Thereafter, TGR testing using gpt delta mice was conducted for liver and glandular stomach (maximum dose $1000 \mathrm{mg} / \mathrm{kg}$ body weight for 28 days by gavage) in FY2009 in order to investigate in vivo mutagenicity. Neither point mutation nor deletion mutation was induced in either organ [H21(FY2009)]. It was concluded that there are no concerns for genotoxicity of erythorbic acid to living bodies.

\section{Piperonal (No. 319 in Table 3)}

In Ames testing at TMRL using TA97 and TA102 this substance showed positive results in TA97 without S9mix at the highest dose of $1 \mathrm{mg} /$ plate [3]. It is reported that a statistically significant increase was observed with S9mix, but the level did not reach twice that of the negative control. There are no reports on chromosomal aberration tests. MN testing using ICR mice was carried out in FY2010, and the results were negative in bone marrow after oral administration of 250,500 and $1000 \mathrm{mg} / \mathrm{kg}$ body weight (two doses at 24-h intervals) [H22(FY2010)]. In FY2010-11, TGR testing using gpt delta mice was performed in the liver and kidney in order to confirm in vivo mutagenicity at doses of 250,500 and $1000 \mathrm{mg} / \mathrm{kg}$ body weight for 28 days by gavage. The results were negative for both organs at doses of 500 and $1000 \mathrm{mg} / \mathrm{kg}$ body weight [H23(FY2011)].

From the above results it was concluded that piperonal does not show genotoxicity in living organisms.

\section{3) One item positive in all three tests (Ames, chromosomal aberration and in vivo micronucleus tests) Maltol}

In 1982, Ames testing using TA100, TA98, TA2637, and TA94 was carried out for maltol at a maximum dose of $10.0 \mathrm{mg} /$ plate, and the results were negative both with and without S9mix [6]. Chromosomal aberration testing was conducted in the same year, and it was reported that structural abnormalities were induced in CHL cells at the highest dose $(0.075 \mathrm{mg} / \mathrm{mL})$ without S9mix [6]. Subsequently, Ames testing was performed at TMRL with TA97 and TA102, at the highest dose of $10.0 \mathrm{mg} /$ plate with and without S9mix. Induction of colony formation at a reversion level almost double that of the negative control was observed in TA97 at a dose of $1 \mathrm{mg} /$ plate without S9mix. Positive judgment has been reported in a micronucleus test using bone marrow of ddY mice, $24 \mathrm{~h}$ after single i.p. administration of 125, 250 and $500 \mathrm{mg} /$ $\mathrm{kg}$ body weight [5]. Since the usage of this item is limited to fragrances, there is no possibility of exposure in vivo at a concentration equivalent to the dose at which chromosomal abnormality was detected in vitro.

In FY2009, TGR testing using gpt delta mice was performed in the liver and glandular stomach for confirmation of in vivo gene mutagenicity. The results were negative in both organs at doses of 400, 200, 100 and $50 \mathrm{mg} / \mathrm{kg}$ body weight for 28 days by gavage [H21(FY2009)].

From the above, it seems that there is no concern of genotoxicity in maltol for living bodies.

\section{4) Five items for which the Ames test was negative 1-Methylnaphthalene}

In FY2005 this substance was reported to have induced structural abnormalities in a chromosome aberration test using CHL cells [H17(FY2005)] while in vivo bone marrow micronucleus testing conducted in FY2006 reported negative results in a two-dose study of $1000 \mathrm{mg} / \mathrm{kg}$ body weight at the maximum [H18(FY2006)].

Regarding mutagenicity, in Ames tests using several strains of Salmonella typhimurium conducted from 1980 to 2002, all results were negative, whereas a weak positive result was reported in the forward mutation test using S. typhimurium (maximum dose $0.992 \mathrm{mg} / \mathrm{mL}$, 2-h exposure) [FSC58]. In theory, the Ames test, which is a reverse mutation test, can detect only specific point mutations while a forward mutation test can detect mutations of any type. Thus, it would be problematic for the 
negative results of the Ames tests to be taken as completely eliminating the concerns about mutagenicity arising from the result of the forward mutation tests. Subsequently, a TGR test in gpt delta mice (males and females) was performed on the lungs. The reason that the lungs were selected as the target organ was that weak carcinogenicity was observed in the lungs of mice in the 81-week chronic toxicity-carcinogenicity combination test reported in 1993. TGR tests were conducted at doses of 170 and $280 \mathrm{mg} / \mathrm{kg}$ body weight for females and 120 and $220 \mathrm{mg} / \mathrm{kg}$ body weight for males by dietary administration for 13 weeks, the results being negative in all conditions ([15], FSC58).

From the above, 1-methylnaphthalene is considered to have no concerns of genotoxicity for living bodies.

\section{Food Red No. 40}

In FY1995 at TMRL negative results (maximum dose 10 $\mathrm{mg} /$ plate) in Ames tests with TA97 and TA102 with and without S9mix were reported [16]. Chromosomal aberration tests have not been carried out. Subsequently, in vivo micronucleus tests using CD1 mice was performed in FY2008, and results of single oral gavage of 500, 1000 and $2000 \mathrm{mg} / \mathrm{kg}$ body weight were reported to be negative in bone marrow [H20(FY2008)].

In FY2008 and FY2011, comet and TGR tests using mice were conducted to examine in vivo DNA damage inducibility and mutagenicity, respectively. In the comet test, $\mathrm{CDF}_{1}$ mice were administered two doses of 500, 1000 and 2000 $\mathrm{mg} / \mathrm{kg}$ body weight by oral gavage with a $24-\mathrm{h}$ interval. The results were negative for both liver and glandular stomach (H20(FY2008), [17]). In addition, another comet assay using ICR mice was carried out with two oral gavage administrations (24-h interval) at doses of 500, 1000 and $2000 \mathrm{mg} / \mathrm{kg}$ body weight. The results were negative in both stomach and colon, while an increase without dose correlation was observed in liver [H23(FY2011)]. TGR testing was conducted using the Muta ${ }^{\text {Tx" }}$ Mouse, orally gavaged at doses of 250,500 and $1000 \mathrm{mg} / \mathrm{kg}$ body weight for 28 days; mutagenicity in the liver and glandular stomach was not observed [H20(FY2008)]. Furthermore, TGR tests using gpt delta mice were carried out and the results were negative for mutagenicity in the large intestine following oral gavage for 28 days at doses of 250, 500 and $1000 \mathrm{mg} / \mathrm{kg}$ body weight [H23(FY2011)].

From the above, it seems that there is no concern of genotoxicity of Food Red No. 40 for living bodies.

\section{Food Red No. 102}

In 1979 negative results were reported following Ames tests carried out with and without S9mix conditions using TA100, TA1535, TA98, TA1537, TA92 and TA94 (maximum dose $5.0 \mathrm{mg} /$ plate) [2]. In chromosomal aberration tests using $\mathrm{CHL}$ cells carried out in the same year, induction of structural abnormalities was observed with
S9mix (maximum dose of $4.0 \mathrm{mg} / \mathrm{mL}$ ) [2]. Subsequently, Ames tests were conducted at TMRL using TA97 and TA102, and the results were negative with and without S9mix (maximum dose $10 \mathrm{mg} /$ plate) [10]. Since chromosomal abnormalities were induced in vitro, micronucleus tests using ddY mice were carried out in FY1980. Results were negative for two sets of conditions in bone marrow: single i.p. administration of 300,600 and $1200 \mathrm{mg} / \mathrm{kg}$ body weight; and four i.p. doses of $300 \mathrm{mg} / \mathrm{kg}$ body weight [13].

In FY2008, comet and TGR tests using mice were carried out to examine in vivo DNA damage inducibility and mutagenicity, respectively [H20(FY2008)]. Comet tests were carried out by oral gavage (twice, at 24-h intervals) at doses of 500, 1000 and $2000 \mathrm{mg} / \mathrm{kg}$ body weight using $\mathrm{CDF}_{1}$ mice, and the results were judged as negative in both liver and glandular stomach. The TGR tests were carried out in Muta ${ }^{\text {Tw }}$ Mouse using oral gavage at 250,500 and $1000 \mathrm{mg} / \mathrm{kg}$ body weight for 28 days, and the results were negative in both liver and glandular stomach.

From the above, Food Red No.102 is considered not to have concerns of genotoxicity to living bodies.

\section{Food Red No. 104}

In 1979, negative results in Ames tests carried out using TA100, TA1535, TA98, TA1537, TA92 and TA94 with and without S9mix (maximum dose $5 \mathrm{mg} /$ plate) were reported [2]. In the same year, chromosomal aberration tests using CHL cells were conducted without S9mix, and the results were negative (maximum dose $0.25 \mathrm{mg} /$ $\mathrm{mL}$ ) [2]. Ames tests were also conducted at TMRL with TA97 and TA102, and the results were negative with and without S9mix (maximum dose $1 \mathrm{mg} /$ plate) [10]. Micronucleus testing using mice was not performed because both in vitro tests were negative.

In FY2008, comet and TGR tests using mice were carried out to confirm in vivo DNA damage inducibility and mutagenicity, respectively. Comet tests for liver and glandular stomach were performed by oral gavage (twice, 24-h interval) at doses of 250,500 and $1000 \mathrm{mg} / \mathrm{kg}$ body weight on $\mathrm{CDF}_{1}$ mice. Results showed false positive in the liver and positive in glandular stomach [H20(FY2008)]. TGR tests were conducted using Muta ${ }^{\text {Tw }}$ Mouse with oral gavage at 250,500 and $1000 \mathrm{mg} / \mathrm{kg}$ body weight for 28 days and liver and glandular stomach were examined for mutation induction; the results were negative in both [H20(FY2008)].

Based on the above results, it is likely that the DNA damage detected in the comet tests would not reach the level necessary to produce mutation. The negative results in liver and glandular stomach in TGR tests support this view, and it seems likely that the DNA damage is repaired in mouse body. Therefore, Food Red No. 104 is considered not to induce genotoxicity (mutagenicity) in vivo. 


\section{Food Red No. 105}

In FY1978 results were negative in Ames tests (maximum dose $5.0 \mathrm{mg} /$ plate) with and without S9mix using TA100, TA1535, TA98, TA1537, TA92 and TA94 [2]. In the same year, chromosomal aberration tests using CHL cells were also carried out (S9mix only) and the results were negative (maximum dose $0.25 \mathrm{mg} / \mathrm{mL}$ ) [2]. Subsequently, Ames tests were carried out at TMRL using TA97 and TA102 (maximum dose $1 \mathrm{mg} /$ plate) with and without S9mix, with negative results [10]. Micronucleus tests using mice were not carried out because both in vitro tests were negative.

In FY2008, in order to examine in vivo DNA damage inducibility and mutagenicity, comet and TGR tests were conducted, respectively, in mice. The comet test was positive in both liver and glandular stomach for oral administration (twice, 24-h interval) at doses of 250, 500 and $1000 \mathrm{mg} / \mathrm{kg}$ body weight for $\mathrm{CDF}_{1}$ mice, and were examined [H20(FY2008)]. The TGR test was conducted using Muta ${ }^{\mathrm{T}}$ Mouse with oral gavage at 250, 500 and $1000 \mathrm{mg} / \mathrm{kg}$ body weight for 28 days. Mutation induction in the liver and glandular stomach was tested for, both results being negative [H20(FY2008)].

Since the TGR tests performed in mouse liver and glandular stomach were negative, the DNA damage detected in the comet test is considered to have been repaired in vivo. Thus, there is a high possibility that such DNA damage would not lead to mutation. In conclusion, there are no concerns that Food Red No. 105 induces genotoxicity (mutagenicity) in vivo.

\section{Discussion}

The standard genotoxicity tests are carried out to detect gene mutation by Ames test using bacteria, and to detect chromosomal abnormalities by an in vitro chromosomal aberration test using cell culture and an in vivo micronucleus test using mice. Chromosomal abnormalities in chromosomal aberration tests are observed as morphological abnormalities in chromosomes during the interphase of cell division because damaged DNA is not normally replicated and the abnormalities persist. Such structural abnormalities are lethal for cells in many cases, and the majority of chromosomal abnormalities are not inherited by the next generation. Similarly, micronuclei in the micronucleus test also transiently appear in daughter cells after cell division, and disappear after the next cell division. Therefore, chromosomal abnormalities and micronuclei are indicators that DNA has been exposed to genotoxic substances, not a cause of cancer in cells. The fragmentation of DNA observed in the comet test is also transient, thus the comet test is also an indicator test. On the other hand, gene mutation is irreversible and permanent. Gene mutations arising in oncogenes or tumor suppressor genes have the possibility to cause cell transformation and initiate cancer-forming cells. Therefore, genetic mutation is a direct trigger of cancer, and it is highly correlated with carcinogenicity in rodents compared to other genotoxic end points [18], while the chromosome aberration test and micronucleus test have high false positive rates and low correlation with carcinogenicity tests [19].

The TGR test, which is an in vivo gene mutation test, is thus recommended when chemical substances have shown positive results in chromosome aberration tests, micronucleus tests, and comet tests. In particular, when comet and TGR tests are carried out on the same target tissue, if the results differ between the two, the results of the TGR tests should be given priority. The TGR test is also useful for follow-up of the same gene mutation test, the Ames test. A false positive reaction sometimes occurs in the Ames test because of bacteria-specific conditions such as drug metabolism, in vitro test-specific reactions using rat $S 9$, as well as nonspecific reactions due to non-physiological conditions differing from the in vivo situation. Confirmation of an indication of mutagenicity with the Ames test by the TGR test in the living body is important on both scientific and safety grounds.

Among the 13 designated food additives covered in the Commentary section, eight items were positive for the Ames test, but the TGR test showed negative results for all of them. As a result, the possibility that these eight food additives exhibit genetic toxicity (especially mutagenicity, which is problematic for living bodies) is eliminated. This knowledge is important to ensure human safety. The TGR test took effect with publication of the OECD Guideline TG488 in 2011 and therefore was not available for implementation at the time of the Hayashi report (2000). We expect the safety of other food additives to be confirmed as TGR test results are accumulated.

\section{Postscript}

In this report, we summarized the data for the most widely used substances in the classification of designated food additives in Japan. Currently we are summarizing the results of genotoxicity tests conducted at MHLW for existing food additives, a group of the next most widely used food additives, in the same way. The reports will be updated from time to time since additions and deletions of items are considered likely in the future.

\section{Additional file}

Additional file 1: References Reports in Japanese. (DOCX 14 kb)

\section{Abbreviations}

CA: Chromosomal aberration test; CHL: Chinese hamster lung; FSC: Food Safety Commission; FY: Fiscal year; MHLW: The Ministry of Health, Labour and Welfare; MN: Micronucleus test; NIHS: National Institute of Health Sciences; OECD: The Organisation for Economic Co-operation and Development; 
TGR: Transgenic rodent gene mutation assay; TMRL: Tokyo Metropolitan Research Laboratories of Public Health

\section{Acknowledgements}

We would like to thank all the authors in the references, and the researchers who conducted the tests and provided the data. The authors wish to express their gratitude to the Food Safety Standards and Evaluation Division, Pharmaceutical Safety and Environmental Health Bureau, Ministry of Health, Labour and Welfare of Japan and Japan Food Additives Association for providing genotoxicity test data of food additives.

\section{Funding}

This work was supported by Health and Labour Sciences Research Grants (H28-Food-General-001 and H30-Food-General-003) from Ministry of Health, Labour and Welfare of Japan.

\section{Availability of data and materials}

Not applicable

\section{Authors' contributions}

$\mathrm{MH}$ conceived of the study and participated in its design and coordination. MY collected the data, created a detailed table and wrote the manuscript. Both authors read and approved the final manuscript.

\section{Ethics approval and consent to participate}

Not applicable

\section{Consent for publication}

Not applicable

\section{Competing interests}

The authors declare that they have no competing interests.

\section{Publisher's Note}

Springer Nature remains neutral with regard to jurisdictional claims in published maps and institutional affiliations.

\section{Received: 21 August 2018 Accepted: 5 December 2018}

\section{Published online: 26 December 2018}

\section{References}

1. Hayashi M, Matsui M, Ishii K, Kawasaki M. Data sheet for mutagenicity evaluation of food additives by Ministry of Health Labour and Welfare (FY1979-FY1998). Environ Mutagen Res. 2000;22:27-44 [in Japanese].

2. Ishidate M Jr, Yoshikawa K, Sofuni T. Mutagenicity tests on food additives (series 1) - the collaborative study supported by the Ministry of Health and Welfare of Japan. Mutagen Toxicity. 1980;12:82-90 [in Japanese].

3. Fujita H, Sumi C, Sasaki M. Mutagenicity test of food additives with Salmonella typhimurium TA97, TA102 (VI). Ann Rep Tokyo Metr Res Lab PH. 1991:42:267-75 [in Japanese]

4. OECD SIDS Initial Assessment Report, Sodium Nitrite, SIAM 20, 2005. http:// www.inchem.org/documents/sids/sids/7632000.pdf

5. Hayashi M, Kishi M, Sofuni T, Ishidate M Jr. Micronucleus tests in mice on 39 food additives and eight miscellaneous chemicals. Food Chem Toxicol. 1988;26:485-500 [in Japanese].

6. Ishidate M Jr, Yoshikawa K, Sofuni T. Mutagenicity tests on food additives (series 4) - the collaborative study supported by the Ministry of Health and Welfare of Japan. Toxicol Forum. 1983;6:671-8 [in Japanese]

7. Fujita H, Sasaki M. Mutagenicity test of food additives with Salmonella typhimurium TA97, TA102 (IV). Ann Rep Tokyo Metr Res Lab PH. 1989;40: 355-62 [in Japanese].

8. Ishidate M Jr, Sofuni T, Yoshikawa K. Mutagenicity tests on food additives (series 3) -. The collaborative study supported by the Ministry of Health and Welfare of Japan. Mutagen Toxicity. 1982;5:579-87 [in Japanese]

9. Ishidate M Jr, Sofuni T, Yoshikawa K. Mutagenicity tests on food additives (series 5) - the collaborative study supported by the Ministry of Health and Welfare of Japan. Toxicol Forum. 1984;7:634-43 [in Japanese].

10. Fujita H, Sasaki M. Mutagenicity test of food additives with Salmonella typhimurium TA97, TA102 (VIII). Ann Rep Tokyo Metr Res Lab PH. 1993:44: 278-87 [in Japanese].
11. Ishidate M Jr, Takizawa Y, Sakabe Y, Ishizaki M, Ito K, Tachi M. Mutagenicity tests on food additives (series 8) - the collaborative study supported by the Ministry of Health and Welfare of Japan. Toxicol Forum. 1987;10:649-54 [in Japanese].

12. Fujita H, Nakano M, Sasaki M. Mutagenicity test of food additives with Salmonella typhimurium TA97, TA102 (III). Ann Rep Tokyo Metr Res Lab PH. 1998;39:343-50 [in Japanese].

13. Ishidate M Jr, Sofuni T, Yoshikawa K. Mutagenicity tests on food additives (series 2) - the collaborative study supported by the Ministry of Health and Welfare of Japan. Mutagen Toxicity. 1981;4:80-9 [in Japanese].

14. Fujita H, Sumi C, Sasaki M. Mutagenicity test of food additives with Salmonella typhimurium TA97, TA102 (VII). Ann Rep Tokyo Metr Res Lab PH. 1992:43:219-27 [in Japanese].

15. Jin M, Kijima A, Suzuki Y, Hibi D, Ishii Y, Nohmi T, Nishikawa A, Ogawa K, Umemura T. In vivo genotoxicity of 1-methylnaphthalene from comprehensive toxicity studies with B6C3F1 gpt delta mice. J Toxicol Sci. 2012;37:711-21.

16. Fujita H, Aoki N, Sasaki M. Mutagenicity test of food additives with Salmonella typhimurium TA97, TA102 (X). Ann Rep Tokyo Metr Res Lab PH. 1995;6:258-64 [in Japanese].

17. Honma M. Evaluation of the in vivo genotoxicity of Allura Red AC (Food Red No.40). Food Chem Toxicol. 2015:84:270-5.

18. Morita T, Hamada S, Masumura K, Wakata A, Maniwa J, Takasawa H, Yasunaga K, Hashizume T, Honma M. Evaluation of the sensitivity and specificity of in vivo erythrocyte micronucleus and transgenic rodent gene mutation tests to detect rodent carcinogens. Mutat Res. 2016;802:1-29.

19. Kirkland D, Aardema M, Henderson L, Müller L. Evaluation of the ability of a battery of three in vitro genotoxicity tests to discriminate rodent carcinogens and non-carcinogens 1 . Sensitivity, specificity and relative predictivity. Mutat Res. 2005;584:1-256.

20. Fujita H, Sasaki M. Mutagenicity test of food additives with Salmonella typhimurium TA97, TA102 (II). Ann Rep Tokyo Metr Res Lab PH. 1987;38:423-30 [in Japanese].

21. Bandyopadhyay A, Ghoshal S, Mukherjee A. Genotoxicity testing of lowcalorie sweeteners: aspartame, acesulfame-K, and saccharin. Drug Chem Toxicol. 2008;31:447-57.

22. WHO Food Additives Series 28, 1991. http://www.inchem.org/documents/ jecfa/jecmono/v28je13.htm

23. Ishidate M Jr, Takizawa Y, Sakabe Y, Ishizaki M, Watabe S, Tachi M, Takemoto K. Mutagenicity tests on food additives (series 9) - the collaborative study supported by the Ministry of Health and Welfare of Japan. Toxicol Forum. 1988;11:663-9 [in Japanese].

24. Fujita H, Aoki N, Sasaki M. Mutagenicity test of food additives with Salmonella typhimurium TA97, TA102 (IX). Ann Rep Tokyo Metr Res Lab PH. 1994;45:191-9 [in Japanese].

25. Fujita H, Sasaki M. Mutagenicity test of food additives with Salmonella typhimurium TA97, TA102 (V). Ann Rep Tokyo Metr Res Lab PH. 1990;41:315-22 [in Japanese].

26. WHO Food Additives Series 13. 1978. http://www.inchem.org/documents/ jecfa/jecmono/v13je11.htm

27. Fujita H, Sasaki M. Mutagenicity test of food additives with Salmonella typhimurium TA97a, TA102 (I). Ann Rep Tokyo Metr Res Lab PH. 1986;37: 447-52 [in Japanese].

28. Hachiya N, Takizawa Y, Kawamura T, Tateno N, Sakabe Y, Asanoma M, Noda $M$, Ishizaki M, Isibashi T, Kuroda K. Outline of the results of acute toxicity and various mutagenicity tests for natural additives (FY1981-FY 1983). Toxicol Forum. 1985;8:91-105 [in Japanese].

29. Fujita H, Kojima A, Sasaki M, Hiraga K. Mutagenicity test of antioxidants and fungicides with Salmonella typhimurium TA97a, TA102. Ann Rep Tokyo Metr Res Lab PH. 1985;36:413-7 [in Japanese]

30. Brusick D, Grotz VL, Slesinski R, Kruger CL, Hayes AW. The absence of genotoxicity of sucralose. Food Chem Toxicol. 2010;48:3067-72.

31. Wild D, King M-T, Gocke E, Eckhardt K. Study of artificial flavouring substances for mutagenicity in the Salmonella/microsome. Basic and micronucleus tests. Food Chem Toxicol. 1983;21:707-19. 